\title{
Thermal Liability of Hyaloclastite in the Krafla Geothermal Reservoir, Iceland: The Impact of Phyllosilicates on Permeability and Rock Strength
}

\author{
Josh Weaver $\mathbb{D}^{1},{ }^{1}$ Guðjón H. Eggertsson $\mathbb{D}^{\mathbb{D}}{ }^{1}{ }^{\text {James }}$ E. P. Utley $\mathbb{D}^{1},{ }^{1}$ Paul A. Wallace $\mathbb{D}{ }^{1}$ \\ Anthony Lamur $\mathbb{D}^{1},{ }^{1}$ Jackie E. Kendrick $\mathbb{D}^{1},{ }^{1}$ Hugh Tuffen $\mathbb{D}^{2},{ }^{2}$ Sigurður H. Markússon $\mathbb{D}{ }^{3}$ \\ and Yan Lavallée $\mathbb{D}^{1}$ \\ ${ }^{1}$ Department of Earth, Ocean and Ecological Sciences, University of Liverpool, 4 Brownlow Street, L69 3GP Liverpool, UK \\ ${ }^{2}$ Lancaster Environment Centre, Lancaster University, LA1 4YQ Lancaster, UK \\ ${ }^{3}$ Landsvirkjun, Háaleitisbraut 68, 110 Reykjavík, Iceland \\ Correspondence should be addressed to Josh Weaver; j.weaver@liverpool.ac.uk
}

Received 21 October 2019; Revised 22 January 2020; Accepted 11 February 2020; Published 14 July 2020

Guest Editor: Enrique Gomez-Rivas

Copyright (C) 2020 Josh Weaver et al. This is an open access article distributed under the Creative Commons Attribution License, which permits unrestricted use, distribution, and reproduction in any medium, provided the original work is properly cited.

Geothermal fields are prone to temperature fluctuations from natural hydrothermal activity, anthropogenic drilling practices, and magmatic intrusions. These fluctuations may elicit a response from the rocks in terms of their mineralogical, physical (i.e., porosity and permeability), and mechanical properties. Hyaloclastites are a highly variable volcaniclastic rock predominantly formed of glass clasts that are produced during nonexplosive quench-induced fragmentation, in both subaqueous and subglacial eruptive environments. They are common in high-latitude geothermal fields as both weak, highly permeable reservoir rocks and compacted impermeable cap rocks. Basaltic glass is altered through interactions with external water into a clay-dominated matrix, termed palagonite, which acts to cement the bulk rock. The abundant, hydrous phyllosilicate minerals within the palagonite can dehydrate at elevated temperatures, potentially resulting in thermal liability of the bulk rock. Using surficial samples collected from Krafla, northeast Iceland, and a range of petrographic, mineralogical, and mechanical analyses, we find that smectite dehydration occurs at temperatures commonly experienced within geothermal fields. Dehydration events at 130 , 185 , and $600^{\circ} \mathrm{C}$ result in progressive mass loss and contraction. This evolution results in a positive correlation between treatment temperature, porosity gain, and permeability increase. Gas permeability measured at $1 \mathrm{MPa}$ confining pressure shows a 3 -fold increase following thermal treatment at $600^{\circ} \mathrm{C}$. Furthermore, strength measurements show that brittle failure is dependent on porosity and therefore the degree of thermal treatment. Following thermal treatment at $600^{\circ} \mathrm{C}$, the indirect tensile strength, uniaxial compressive strength, and triaxial compressive strength (at $5 \mathrm{MPa}$ confining pressure) decrease by up to $68 \%$ $(1.1 \mathrm{MPa}), 63 \%(7.3 \mathrm{MPa})$, and $25 \%(7.9 \mathrm{MPa})$, respectively. These results are compared with hyaloclastite taken from several depths within the Krafla reservoir, through which the palagonite transitions from smectite- to chlorite-dominated. We discuss how temperature-induced changes to the geomechanical properties of hyaloclastite may impact fluid flow in hydrothermal reservoirs and consider the potential implications for hyaloclastite-hosted intrusions. Ultimately, we show that phyllosilicatebearing rocks are susceptible to temperature fluctuations in geothermal fields.

\section{Introduction}

Reservoir rocks in geothermal fields are exposed to thermal fluctuations from natural [1] and anthropogenic temperature sources [2]. These fluctuations range from $\sim 250^{\circ} \mathrm{C}$ of cooling during thermal stimulation practices [3] to heating of up to $400^{\circ} \mathrm{C}$ during flow testing [4] and up to $\sim 1200^{\circ} \mathrm{C}$ during basaltic magma intrusions [5]. Importantly, for the sustainability of hydrothermal systems, temperature variations cause volumetric changes that may impart damage [6-12] and have the potential to trigger mineral reactions, prompting precipitation or breakdown [13] in altered reservoir rocks 
[14]. These reactions can affect key reservoir rock properties, such as porosity, permeability, and strength [15], which may influence the capacity for fluid circulation $[16,17]$ and thus dictate energy production potential [18]. Understanding the lithology-specific development of these properties in response to temperature is important for improved fluid flow modelling in geothermal fields.

Hyaloclastite is a rock type prevalent in subaqueous and high-latitude, glaciated regions such as Iceland, where it forms a major reservoir constituent in several geothermal fields [19-21]. It is often highly porous and permeable, such that it is frequently targeted for geothermal production, shallow freshwater aquifers, or carbon reinjection and mineralisation [22-24], but it is also weak and can collapse to form a mechanically sealed, impermeable caprock [25]. Hyaloclastites are highly variable, altered volcaniclastic breccias that form explicitly by severe quench-induced fragmentation of magma interacting with a large volume of external water or ice [26]. However, the term is often applied ambiguously in the literature to any lava fragmented by interaction with water [27]; consequently, it is commonly identified in a wide range of water-rich environments, such as mid-ocean ridges [28], seamounts [29, 30], submarine volcanic flanks [31, 32], subglacial tuyas [33], tindar ridges [34, 35], nearshore waters [36], and emergent islands $[37,38]$. Therefore, hyaloclastite is more appropriately considered a non-genetic term [39] that is more accurately defined by the descriptive lithological criteria, used herein, of quench-fragmented sideromelane (i.e., basaltic glass) supported by a palagonite matrix [40]. This is in contrast to the largely cohesionless perlite, which is produced following the hydration-induced alteration of the dacitic and rhyolitic glasses [41].

The abundance of palagonite in hyaloclastites arises from the inherent metastable nature of basaltic volcanic glass exposed to fluids [42], especially at moderate to high temperatures $[43,44]$. Palagonite is considered the first alteration product of mafic glass; it forms initially as an amorphous phase during the complex, concurrent processes of glass hydration and devitrification $[45,46]$. The crystallographic character of palagonite is time-dependent, transitioning from a clear amorphous phase displayed in concentric bands of gel-palagonite to a highly variable assortment of crystal habits (e.g., fibrous, lath-like, or granular structure) termed fibro-palagonite. Fibro-palagonite is commonly dominated by clays, namely smectite, and zeolites $[47,48]$.

Rocks composed of clay and zeolite minerals tend to be highly sensitive to moderate thermal fluctuations on the order of a few hundred degrees Celsius [49]. In particular, high temperatures may trigger devolatilisation reactions that prompt the breakdown of these minerals. This occurrence leads to a loss of material that results in the creation of porosity, thereby affecting the strength and permeability of the rock [49-51]. This is also true for incomplete reactions in rocks experiencing short excursions to high temperature [52]. In the case of palagonite undergoing a temperature increase, dehydration can begin below $200^{\circ} \mathrm{C}$ and result in greater mass loss than in many other clays [53]. This suggests hyaloclastite may be particularly susceptible to thermally induced devolatilisation reactions that are likely to affect geomechanical properties [49].

Here, we investigate the impact of thermal treatment on hyaloclastite, constraining the mineralogical, mechanical, and physical evolution at a range of temperatures up to $600^{\circ} \mathrm{C}$.

\section{Material and Methods}

2.1. Overview. Samples were initially characterised using a suite of thermal analysis equipment in order to select a series of treatment temperatures at which the hyaloclastite would be analysed in further detail. After fully characterising the mineralogical, physical, and mechanical properties of the as-collected material, cores were dwelled at the selected treatment temperature and cooled to room temperature; petrographic observations were made; and the impact on mineralogy, mass, porosity, permeability, and strength was determined.

2.2. Materials. Krafla caldera, located in northeast Iceland (Figure 1), hosts a well-developed geothermal field operated by Landsvirkjun, the national power company of Iceland. The caldera infill is dominated by hyaloclastite and basaltic intrusions to a depth of $1300 \mathrm{~m} \mathrm{[21],} \mathrm{which} \mathrm{comprise} \mathrm{the} \mathrm{res-}$ ervoir rock hosting hydrothermal fluids harnessed for heating and energy production [54]. The surficial sample block was collected from the southeastern caldera edge $\left(65^{\circ} \mathrm{N}\right.$ 41.067; $-16^{\circ} \mathrm{W} 43.089$ ) in August 2015, where the outcrops protrude from the surface and are isolated from the hydrothermal reservoir, thus undergoing trivial debilitation from exposure to the high-temperature reservoir fluids. However, the youngest and shallowest hyaloclastites at Krafla formed during the last glacial period [55] and have possibly been buried and then subsequently exhumed due to glacial erosion [56]. To complement these 'fresh' samples, a limited suite of subsurface samples was retrieved during the coring of boreholes KH-4 $(70 \mathrm{~m})$ and KH-6 $(556 \mathrm{~m}$ and $732 \mathrm{~m})$ by Landsvirkjun. The in situ sample temperatures were recorded during and after drilling of the wells; the $70 \mathrm{~m}$ sample from $\mathrm{KH}-4$ was measured at $41^{\circ} \mathrm{C}$ during drilling, whilst after leaving borehole $\mathrm{KH}-6$ to thermally equilibrate for one week, the $556 \mathrm{~m}$ and $732 \mathrm{~m}$ depths were measured at 145 and $125^{\circ} \mathrm{C}$, respectively [57]. Note that the sample collected from $556 \mathrm{~m}$ depth may have interacted with a basaltic dyke, located approximately $1 \mathrm{~m}$ below. The surficial sample was chosen to ensure it was texturally representative of the local geology and similar to the subsurface samples in terms of clast size and abundance. Upon visual inspection, the selected sample was relatively homogenous and lacked large features such as fractures or clasts greater than $1 \mathrm{~cm}$ in diameter. For all the mechanical and permeability measurements, heterogeneities were limited to less than $10 \%$ of the sample size of $26 \mathrm{~mm}$ by $52 \mathrm{~mm}$ for cores and $26 \mathrm{~mm}$ by $13 \mathrm{~mm}$ for discs. Following sample preparation and prior to all testing, samples were oven-dried at $70^{\circ} \mathrm{C}$ for 4 hours and subsequently stored in a desiccator at room temperature. All samples were prepared, characterised, and tested at the University of Liverpool. 




Figure 1: A map of the Krafla geothermal field showing the location of the surficial sampling site, subsurface sampling sites (boreholes KH-4 and $\mathrm{KH}-6)$, the Krafla power plant and local geomorphological features. Faults associated with the Krafla caldera complex are marked in black.

2.3. Simultaneous Thermal Analysis (STA). Mass loss and heat capacity were measured against temperature concurrently in a Netzsch STA 449 F1 Jupiter using a simultaneous thermal analyser (STA), which combines thermogravimetric analysis and differential scanning calorimetry (TGA-DSC). Samples were cored to $6 \mathrm{~mm}$ by $1 \mathrm{~mm}$ discs and loaded into a platinum crucible. Prior to each test run, the sample chamber was purged with argon gas and exhausted to vacuum conditions. Each test was initially conducted with an empty crucible to provide a correction baseline, a second time containing a sapphire standard with the same sample dimensions, to correlate the DSC data, and a final time containing the hyaloclastite sample. All temperature profiles were initially heated to $50^{\circ} \mathrm{C}$ at $2^{\circ} \mathrm{C} / \mathrm{min}$ for a 10 -minute isothermal period. For surficial samples, constant-rate temperature profiles, heated to $700^{\circ} \mathrm{C}$ at 5,10 , and $20^{\circ} \mathrm{C} / \mathrm{min}$, as well as stepped isothermal profiles, consecutively heated to each treatment temperature at $5^{\circ} \mathrm{C} / \mathrm{min}$ and dwelled for 12 hours, were conducted. For subsurface samples, constantrate temperature profiles were heated to $700^{\circ} \mathrm{C}$ at a rate of $10^{\circ} \mathrm{C} / \mathrm{min}$ only. Data was collected from $50^{\circ} \mathrm{C}$ at a $0.1-$ minute resolution, with mass accurate to $0.025 \mu \mathrm{g}$ and heat capacity to $\pm 2 \%$.
2.4. Thermomechanical Analysis (TMA). Absolute thermal expansion coefficients were recorded using a Netzsch TMA 402 F1 Hyperion. Samples were cored in to cylinders measuring $6 \mathrm{~mm}$ in diameter by $5 \mathrm{~mm}$ in height. A core sample was loaded between the piston of the TMA, and the furnace was sealed shut around the sample assembly. Prior to each test, the sample chamber was purged with argon gas and exhausted to vacuum conditions. For each test, the temperature and load profiles were completed twice; initially, a ceramic cylinder, matching the sample proportions to within $5 \%$, was used to supply a correction baseline that was removed from the second test run containing the hyaloclastite sample; this allowed an accurate determination of the sample length changes. All temperature profiles were initially heated to $40^{\circ} \mathrm{C}$ at $2^{\circ} \mathrm{C} / \mathrm{min}$ for a 10 -minute isothermal period. Constant-rate temperature profiles, heated to $700^{\circ} \mathrm{C}$ at 5,10 , and $20^{\circ} \mathrm{C} / \mathrm{min}$, were completed using a $1 \mathrm{~N}$ load. Subsurface samples were heated to $700^{\circ} \mathrm{C}$ at a constant rate of $5^{\circ} \mathrm{C} / \mathrm{min}$. Data was collected at a 0.01 -minute resolution, with height change accurate to $1.25 \mathrm{~nm}$ and load to $0.01 \mathrm{mN}$.

2.5. Thermal Treatment. Thermal treatment temperatures of $130^{\circ} \mathrm{C}, 185^{\circ} \mathrm{C}, 400^{\circ} \mathrm{C}$, and $600^{\circ} \mathrm{C}$ were selected following the 
TGA-DSC and TMA measurements. Sample cores, $26 \mathrm{~mm}$ in diameter by $52 \mathrm{~mm}$ in height, and Brazilian discs, $26 \mathrm{~mm}$ in diameter by $13 \mathrm{~mm}$ in height, were thermally treated in a Carbolite CWF 1300 box furnace, to be compared against the ascollected samples. Samples were heated at $5^{\circ} \mathrm{C} / \mathrm{min}$ and, once at target temperature, were left to dwell for 12 hours before being cooled to room temperature at a rate of $5^{\circ} \mathrm{C} / \mathrm{min}$.

2.6. Mineralogical Analysis. The mineralogical and textural changes at each treatment temperature were investigated using a combination of X-ray diffraction (XRD) analysis, optical microscopy, and quantitative evaluation of minerals by scanning electron microscopy (QEMSCAN). Adjacent samples were cored and subjected to the temperature profile for each of the treatment temperatures discussed above in order to prepare samples for mineralogical analysis; parts of these rocks were cut for thin section preparation, and the rest was crushed to powder (see below). Adjacent samples were selected to minimise potential mineralogical differences from within the hyaloclastite, which are petrogenetically heterogeneous.

XRD analysis was completed on the dried, glycolated, and clay-separated samples using a Panalytical X'Pert Pro MPD diffractometer fitted with an X'Celerator detector. Texturally representative rocks were crushed, in distilled water, to a powder $<10 \mu \mathrm{m}$ using an agate McCrone micronising mill, and subsequently dried at $60^{\circ} \mathrm{C}$ before being further crushed into a loose powder using an agate pestle and mortar. Clay-separated samples were partially crushed in a ceramic pestle and mortar and then prepared with ultrasonication in distilled water, with the equivalent spherical particle size selected for by standard centrifugation methods. Clayseparated samples were then dried at $60^{\circ} \mathrm{C}$ and recrushed into a light random powder. For glycolated samples, saturation of a random powder was achieved by using ethylene glycol by vapour pressure at $60^{\circ} \mathrm{C}$, for 24 hours. Samples were backloaded into cavity holders as random powders. A copper $\mathrm{X}$-ray tube was used, with a Ni filter to select for $\mathrm{Cu} \mathrm{K}-\alpha$ radiation. Scans covered the 2 theta range of $4-70^{\circ}$. Data was analysed using the Relative Intensity Ratio (RIR) method within the HighScore Plus ${ }^{\circledR}$ software, alongside reference patterns from the International Centre for Diffraction Data, Powder Diffraction File 2 Release 2008.

Mineral distribution was imaged at $20 \mu \mathrm{m}$ resolution for each thin section and at $4 \mu \mathrm{m}$ resolution for selected sites, using Scanning Electron Microscope Energy-Dispersive Xray Spectroscopy (SEM-EDS) on uncovered, carbon-coated thin sections imbedded with luminescent dye. Using a QEMSCAN developed by FEI, elemental chemistry was mapped and quantified using two Bruker EDS detectors and matched to known compositions of minerals and glasses. Crystallographic features are not recorded, preventing the differentiation of polymorphs and mineral dissociation (in the case where chemical transport is limited). Mineral and glass abundance was quantified at $20 \mu \mathrm{m}$ resolution by comparing the relative proportions of pixels in each image, normalised against the pore space.

2.7. Porosity Determination. Prior to and following thermal treatment, the skeletal volume of each sample (i.e., the vol- ume of solid rock, including isolated pore space) was measured using a Micromeritics AccuPyc II 1340 Helium Pycnometer, accurate to $\pm 0.1 \%$ of the measured volume. The connected porosity $(\phi)$, into which fluids are able to flow, was then determined by the ratio of the connected pore volume (equivalent to the difference between the core volume $\left(V_{\mathrm{c}}\right)$ and the measured skeletal volume $\left.\left(V_{\mathrm{m}}\right)\right)$ to the core volume $\left(V_{c}\right)$, such that:

$$
\phi=\frac{V_{\mathrm{c}}-V_{\mathrm{m}}}{V_{\mathrm{c}}} .
$$

2.8. Permeability Measurements. Gas permeability was measured for each sample core, prior to and following thermal treatment, using a Vinci Technologies gas permeameter with nitrogen gas. The $26 \mathrm{~mm}$ by $52 \mathrm{~mm}$ sample cores were inserted into a compressible Viton jacket and loaded to $1 \mathrm{MPa}$ confining pressure using a manual valve. Gas flow was automatically set to a constant rate through the sample, which increased by a factor of 2 until a differential pressure of $>0.5$ psi was achieved between the inlet and the outlet. The flow rate values ranged from 33 to $190 \mathrm{~cm}^{3} / \mathrm{min}$. The sample permeability $(k)$ was calculated using Darcy's law:

$$
Q=\frac{-k A \Delta P}{\mu L},
$$

where $Q$ is the flow rate; $A$ is the cross-sectional surface area of the sample; $\Delta P$ is the pressure differential, accurate to $1 \%$ full scale, measured across the sample; $\mu$ is the viscosity of the liquid (in this case nitrogen); and $L$ is the sample length.

For selected cores, steady-state water permeability was also measured in a hydrostatic loading cell from Sanchez Technologies. Within the load cell, the $26 \mathrm{~mm}$ by $52 \mathrm{~mm}$ sample cores were inserted into an impermeable Viton jacket and loaded to the desired effective pressure (confining pressure-pore pressure). Confining pressure was applied using low-viscosity silicone oil, and pore pressure was applied using demineralised water. Permeability was measured by maintaining $2 \mathrm{MPa}$ of pore pressure at one side of the sample and $1 \mathrm{MPa}$ of pore pressure at the other, such that a constant $1 \mathrm{MPa}$ pressure differential was upheld with an average pore pressure of $1.5 \mathrm{MPa}$, and the flow rate was measured, accurate to $0.01 \mathrm{ml} / \mathrm{min}$. For each sample, the permeability was measured at $5 \mathrm{MPa}$ confining pressure increments consecutively, up to $30 \mathrm{MPa}$, to simulate depths up to and in excess of the deepest hyaloclastite units at Krafla. To ensure that permeability was measured under steady-state conditions and that no gas slippage was occurring, the need for the Klinkenberg [58] and Forchheimer [59] corrections was assessed for each sample and found to not be required for any of the samples in both the gas and water permeameters.

Porosity change associated with fracture closure during loading was also recorded in the hydrostatic cell, prior to each permeability measurement [8], using the monitored volume of water that was expelled from the sample. However, absolute porosity variations are not reported as volume change is not monitored during the first loading step; instead, 
the porosity reduction (in \%) is calculated from the initial porosity measured by helium pycnometry. Note that due to potential damage inflicted during loading, samples measured in the hydrostatic load cell were not used for subsequent strength testing.

2.9. Strength Measurements. The uniaxial and triaxial compressive strength tests and indirect tensile strength tests were performed on the as-collected and thermally treated (TT) samples at dry, ambient room temperature conditions.

The uniaxial compressive strength (UCS) of the rocks was determined using an 8800 Instron uniaxial press. Cylindrical rock cores, for which porosity and gas permeability had been measured, were loaded at a constant strain rate of $10^{-5} \mathrm{~s}^{-1}$ until failure. Load was recorded with a resolution of $0.1 \mathrm{~s}$ at $10 \mathrm{~Hz}$.

The compressive triaxial strength (TXL) of cores subjected to various confining pressures was measured using a Sanchez Technologies TRIAX100 press. Here again, cylindrical rock cores for which porosity and permeability had been determined were placed between the pistons and jacketed using an impermeable Viton sleeve. The sample assembly was subjected to confining pressure $\left(P_{c}\right)$ by introducing argon gas in the pressure vessel; $5 \mathrm{MPa}$ confining pressure was applied to each sample whilst a constant $1 \mathrm{MPa}$ differential stress was maintained by controlling the axial load. Note that no pore pressure was applied, so that the confining pressure is equivalent to the effective pressure. Upon reaching the confining pressure, the sample was axially deformed at a strain rate of $10^{-5} \mathrm{~s}^{-1}$ until rupture, denoted by a stress drop in the mechanical data, or until a stress plateau was reached. The confining pressure, pore pressure, axial stress, and sample deformation were recorded at $1 \mathrm{~Hz}$.

Young's modulus, calculated by dividing stress over strain, was derived using the gradient of the manually defined, elastic linear loading section of each uniaxial and triaxial strength curve.

The indirect tensile strength (UTS) of the samples was measured by employing the Brazilian disc method using a 5969 Instron uniaxial press. Here, cylindrical discs, $26 \mathrm{~mm}$ diameter by $13 \mathrm{~mm}$ thickness, were radially loaded at a constant deformation rate of $26 \mu \mathrm{m} / \mathrm{s}$ until a stress drop was recorded, associated with failure. Sample deformation, accurate to $\pm 0.1 \mu \mathrm{m}$, and load were recorded with a resolution of $0.05 \mathrm{~s}$, and the tensile strength, $\sigma_{\mathrm{t}}$, was calculated following the ASTM 2008 standard:

$$
\sigma_{\mathrm{t}}=\frac{2 P}{\pi L D}
$$

where $P$ is the maximum applied load (in $\mathrm{N}$ ) and $L$ and $D$ are the thickness and diameter of the specimen (in $\mathrm{m}$ ), respectively.

Note that the mechanical data was corrected for compliance of the loading frame of each press in accordance with the ASTM D7070-16 standard procedure.

\section{Results}

3.1. Simultaneous Thermal Analysis. Thermogravimetric analysis (TGA) reveals progressive, nonlinear mass loss upon heating above $50^{\circ} \mathrm{C}$ (Figure 2(a)). For the surficial samples (referred to as $0 \mathrm{~m}$ ), mass loss is initially negatively correlated with the heating rate, whereby mass is lost more rapidly at low heating rates; however, beyond $250^{\circ} \mathrm{C}$, there is no correlation and the mass loss at $700^{\circ} \mathrm{C}$ ranges from 7 to $10 \%$, reflecting sample heterogeneity. In contrast, the subsurface samples (referred to by their sampling depths of $70 \mathrm{~m}$, $556 \mathrm{~m}$, and $732 \mathrm{~m}$ ) have distinct multistep mass loss shoulders around $100-200^{\circ} \mathrm{C}$ and $475-600^{\circ} \mathrm{C}$; yet, the magnitude of mass loss in each of these temperature ranges varies with depth. Ultimately, the fraction of mass lost is higher in surficial samples than in subsurface samples.

Differential scanning calorimetry measurements associated with the above thermogravimetric analysis reveal further details associated with the mass loss events (Figure 2(b)). The surface samples show double-shouldered endothermic peaks at $130^{\circ} \mathrm{C}$ and $185^{\circ} \mathrm{C}$ (Figure 2(b)), consistent with the 100 $200^{\circ} \mathrm{C}$ mass loss event recorded by the TGA (Figure 2(a)). With the increased heating rate, the endothermic peaks are pushed to slightly higher temperatures (up to $\sim 150^{\circ} \mathrm{C}$ and $220^{\circ} \mathrm{C}$ at $\left.20^{\circ} \mathrm{C} / \mathrm{min}\right)$. At a higher temperature, a faint shoulder develops around $300^{\circ} \mathrm{C}$ and a broad, low-magnitude peak is evident around $650^{\circ} \mathrm{C}$; yet, neither corresponds to distinct mass loss events in Figure 2(a). In contrast, the subsurface samples exhibit a less substantial double-shouldered peak at $130^{\circ} \mathrm{C}$ and $185^{\circ} \mathrm{C}$ than the surficial samples and faint, broad peaks around $300^{\circ} \mathrm{C}$; however, they display strong endothermic peaks at high temperatures: for the $70 \mathrm{~m}$ sample, a wide peak develops between $550^{\circ} \mathrm{C}$ and $660^{\circ} \mathrm{C}$; for the sample from $556 \mathrm{~m}$, the data show a peak at $525^{\circ} \mathrm{C}$; and for the sample from $732 \mathrm{~m}$, the data show a peak at $560^{\circ} \mathrm{C}$.

Based on the simultaneous thermal analysis (Figures 2(a) and 2(b)), four temperatures were selected as thermal treatment targets: $130,185,400$, and $600^{\circ} \mathrm{C}$. Results from the 12-hour isothermal TGA measurements at these temperatures show that mass reaches a new stable value over long time periods, resulting in mass loss of $5 \%, 5.8 \%, 7.1 \%$, and $7.5 \%$, respectively (Figure $2(\mathrm{c})$ ).

3.2. Thermomechanical Analysis (TMA). Thermomechanical analysis was employed to constrain the length changes associated with the mass loss events observed in Figure 2(a). Surface samples initially exhibit limited thermal expansion, followed by minor contraction between $110^{\circ} \mathrm{C}$ and $290^{\circ} \mathrm{C}$ (Figure 2(d)). A return to limited thermal expansion ends at $500^{\circ} \mathrm{C}$, after which significant contraction occurs. The temperature of the maximum extent of contraction between $110^{\circ} \mathrm{C}$ and $290^{\circ} \mathrm{C}$ and the rate of collapse beyond $500^{\circ} \mathrm{C}$ are positively correlated with the heating rate. Subsurface samples from $70 \mathrm{~m}$ depth show moderate expansion up to $475^{\circ} \mathrm{C}$, at which point expansion ceases, before rapidly accelerating beyond $640^{\circ} \mathrm{C}$. Note that a visual inspection of the two $70 \mathrm{~m}$ samples, following the TMA analysis, indicated the occurrence of vesiculation of the glass phase; we do not 

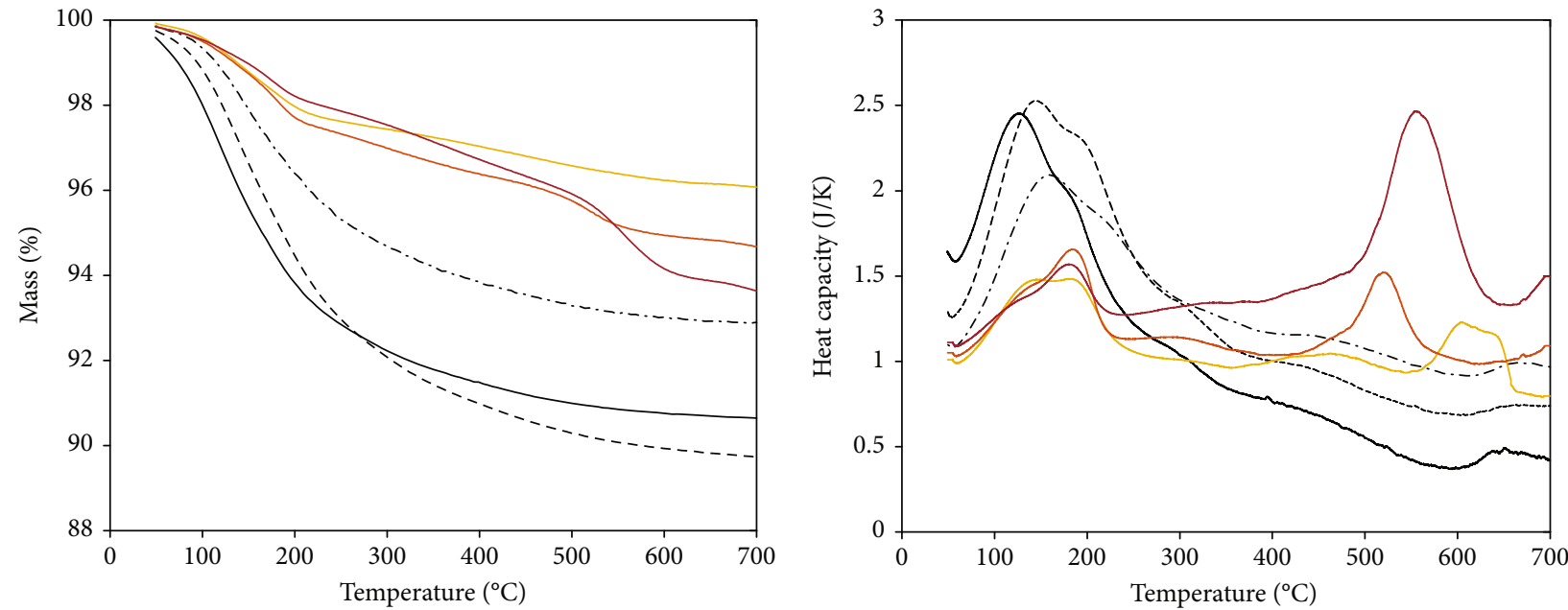

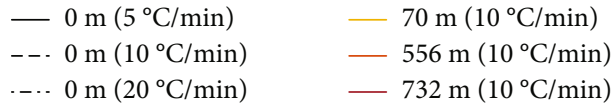

(a)

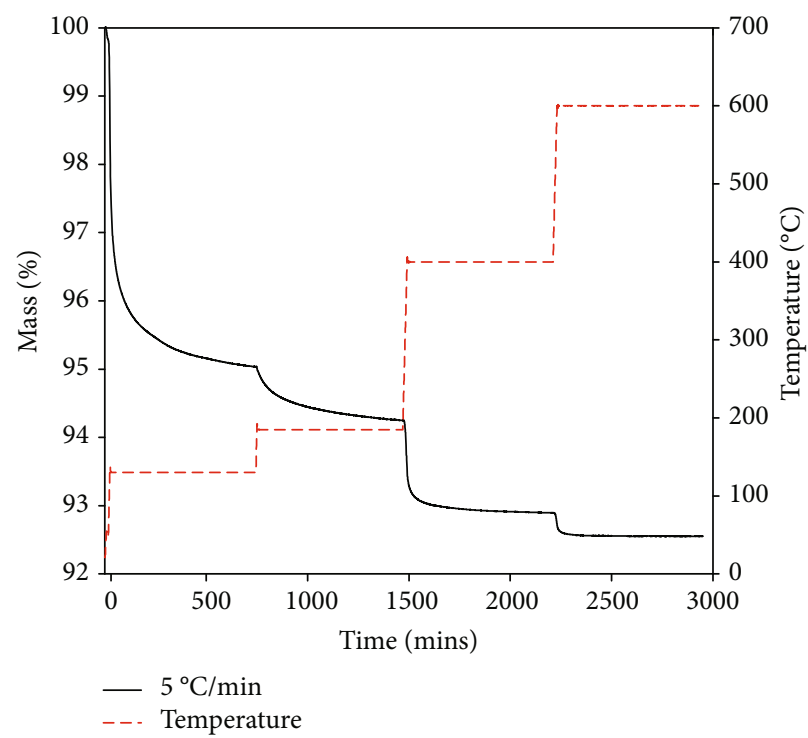

(c)

$$
\begin{aligned}
& \text { - } 0 \mathrm{~m}\left(5^{\circ} \mathrm{C} / \mathrm{min}\right) \\
& \text { - . } 0 \mathrm{~m}\left(10^{\circ} \mathrm{C} / \mathrm{min}\right) \\
& 70 \mathrm{~m}\left(10^{\circ} \mathrm{C} / \mathrm{min}\right) \\
& \text {... } 0 \mathrm{~m}\left(20^{\circ} \mathrm{C} / \mathrm{min}\right) \\
& \text { - } 556 \mathrm{~m}\left(10^{\circ} \mathrm{C} / \mathrm{min}\right) \\
& \text { - } 732 \mathrm{~m}\left(10^{\circ} \mathrm{C} / \mathrm{min}\right)
\end{aligned}
$$

(b)

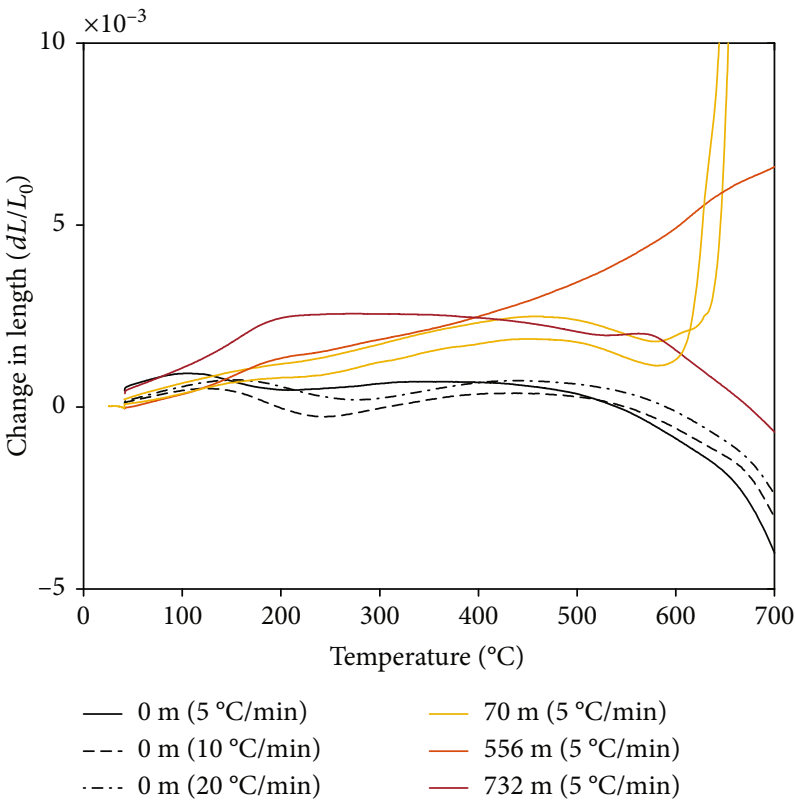

(d)

FIgURE 2: Thermal analysis using TGA-DSC and TMA. (a) Fixed-rate TGA showing thermally induced mass loss for the surficial and subsurface hyaloclastites. (b) Fixed-rate DSC showing low-temperature heat capacity peaks against temperature for surficial samples and high-temperature peaks for subsurface samples. (c) TGA showing mass loss during the sequential 12-hour isothermal dwells, for surficial hyaloclastite. (d) Fixed-rate TMA for the surficial and subsurface samples, showing volumetric collapse for surficial material and a range of depth-dependent responses for subsurface material.

study this further as no surficial samples underwent such a process. The $556 \mathrm{~m}$ sample is entirely dominated by thermal expansion up to $700^{\circ} \mathrm{C}$, whilst the $732 \mathrm{~m}$ sample expands rapidly up to $185^{\circ} \mathrm{C}$ and collapses beyond $\sim 575^{\circ} \mathrm{C}$.

3.3. Mineralogical Analysis. A range of mineralogical and petrographic techniques were applied to further investigate the crystallographic and textural impact of suspected reactions. XRD analysis (Table 1) shows that the surficial hyaloclastite is primarily composed of the common mafic igneous min- erals, anorthite, augite, and quartz, along with secondary minerals chabazite (i.e., zeolite group) and smectite (i.e., clay group). The analysis indicates that, other than small fluctuations in the anorthite and augite proportions, the mineralogical assemblage remains essentially stable up to $130^{\circ} \mathrm{C}$. The fraction of smectite identified in the samples decreases by $\sim 6 \%$ following treatment to $185^{\circ} \mathrm{C}$ and is mostly absent beyond $400^{\circ} \mathrm{C}$ (Table 1). Analysis of the X-ray diffractograms show that the $\mathrm{d}(060)$ peak for unaltered surficial material is at $1.535 \AA$, whist the $\mathrm{d}(001)$ peak expands from $15 \AA$ to $16.2 \AA$ 
TABLE 1: Primary mineralogy identified by X-ray diffraction analysis of hyaloclastite that has experienced different thermal treatment temperatures. Note that the reduction in the smectite proportion causes the relative proportions of the other components to increase and that the presence of sideromelane is not quantified nor included in this analysis.

\begin{tabular}{lccccc}
\hline Temperature experienced: & $20^{\circ} \mathrm{C}$ & $130^{\circ} \mathrm{C}$ & $185^{\circ} \mathrm{C}$ & $400^{\circ} \mathrm{C}$ & $600^{\circ} \mathrm{C}$ \\
\hline Anorthite (\%) & 52 & 59 & 60 & 63 & 73 \\
Augite (\%) & 17 & 13 & 18 & 25 & 17 \\
Chabazite (\%) & 8 & 8 & 7 & 5 & 7 \\
Quartz (\%) & 3 & 2 & 2 & 6 & 3 \\
Smectite (\%) & 19 & 18 & 13 & Trace & Trace \\
Total (\%) & 99 & 100 & 100 & 99 & 100 \\
\hline
\end{tabular}

upon glycolation and collapses to $10 \AA$ after dwelling at $400^{\circ} \mathrm{C}$ for 12 hours, typical of saponite (Supplementary Figure 1). XRD analysis of the subsurface hyaloclastite from Lévy et al. [60] highlights that the smectite transitions from saponite in the surficial and shallow hyaloclastites to interlayered saponite-chlorite in the deeper $(556 \mathrm{~m}$ and $732 \mathrm{~m}$ ) hyaloclastites.

Petrographic analysis provides a textural counterpart to the quantitative mineralogical XRD. Thin section analysis, using both optical microscopy and scanning electron microscopy, reveals the highly variable nature of hyaloclastite (Figure 3). In particular, we note significant textural heterogeneity in terms of glass distribution and geometry, crystal fraction and size, and pore space distribution (Figure 3). The pore space is shown to be predominantly hosted in the matrix in both the as-collected and TT samples (Figures 3(b) and 3(r)), with additional, isolated porosity hosted within the highly variable vesicular glass clasts (Figure 3(j)). Textural examination of the thin sections for the as-collected material shows a low quantity of intra-mineral microfractures within the phenocrysts and glass (Figure 3(b)). A qualitative inspection of the TT sample thin sections found a comparable number of intra-mineral microfractures. Given the material heterogeneity, we do not quantify this further, finding that material characterisation which examines porosity and permeability before and after TT on the same sample to be a more robust measure of sample evolution with TT. Thin section analysis also offers no evidence of reaction rims around crystals or of sintering textures, such as particle necking during agglutination occurring during TT (Figure 3). Changes in the abundance of constituent phases as a result of TT are revealed by QEMSCAN (Table 2, Figure 3). Changes in crystallinity are not recorded in the QEMSCAN maps, and so the dissociation of smectite is not quantified; however, the textural evolution highlights that the porosity increase is dominated by changes in the matrix, which we associate with a reduction in smectite revealed by XRD (from $\sim 19 \%$ to trace content at TT $>400^{\circ} \mathrm{C}$, Table 1 ). Loss of smectite with temperature results in an irregular desiccated texture, distinct from a fractured surface due to its smoother edges and globular distribution (Figures 3(b) and 3(r)), causing the matrix to transition from a continuous, pervasive network (Figures 3(c) and $3(\mathrm{~g})$ ) to discrete patches with increasing
TT temperature, particularly in the $400^{\circ} \mathrm{C}$ and $600^{\circ} \mathrm{C}$ samples (Figures 3(o) and 3(s)).

3.4. Thermally Induced Changes in Porosity and Permeability. The evolution of mass during thermal treatment is reported for the $26 \mathrm{~mm}$ by $52 \mathrm{~mm}$ samples in order to explore the impact of material heterogeneity, discussed in Section 3.3, on mass loss (indicated by thermal analysis in Section 3.1). Sample mass change in the surface cores is positively correlated with the TT (Figure 4(a)). The samples cored from the as-collected material show a large degree of heterogeneity in the material properties despite being sourced from a single block $\sim 40 \mathrm{~cm}$ in length. This hyaloclastite heterogeneity corresponds to substantial scatter in the porosity-gas permeability relationship (Figure 4(b)). However, the effect of this scatter can be accounted for and removed from the TT data by normalising the pore volume fraction change against the initial skeletal volume fraction of the corresponding core prior to TT, $\phi_{\mathrm{I}}$ :

$$
\bar{\phi}=\frac{\phi_{\mathrm{I}}-\phi_{\mathrm{P}}}{1-\phi_{\mathrm{I}}},
$$

where $\phi_{\mathrm{P}}$ is the post-thermal treatment porosity; similarly, the resultant permeability changes are normalised by dividing the post-thermal treatment sample permeability with the original sample permeability (Figure 4(c)). The normalised plot shows that the permeability and porosity changes of all samples increase with TT (Figure 4(c)).

The water permeability of the hyaloclastite measured in the hydrostatic cell shows a negative correlation with effective pressure (Figure 5(a); Supplementary Table 1) as the permeable pathways are constricted by pore space closure (Figure 5(b)). Again, the samples exhibit a large degree of scatter in permeability for all TTs, which is independent of the mass change induced by TT. The as-collected samples as well as those $\mathrm{TT}$ to $130^{\circ} \mathrm{C}$, and to an extent $185^{\circ} \mathrm{C}$, show a moderate-to-large drop in permeability above $17.5 \mathrm{MPa}$ that is not observed in the 400 and $600^{\circ} \mathrm{C}$ TT samples. These effective pressure thresholds are also observed in the porosity evolution plot (Figure 5(b)), which shows a transition from low to high densification with effective pressure across these values. The samples that have been TT to higher temperatures exhibit contrasting evolution of permeability and porosity with effective pressure.

In these cases, the permeability of samples does not change significantly with effective pressure (Figure 5(a)), whilst the porosity shuts linearly with effective pressure (Figure 5(b)); the exception to this behaviour is for one sample (thermally treated to $400^{\circ} \mathrm{C}$ ) which shows an increase in permeability between 7.5 and 17.5 MPa (Figure 5(a)); interestingly, this sample was accompanied by almost no porosity decrease between 17.5 and 23.5 $\mathrm{MPa}$ (Figure 5(b)).

3.5. Thermally Induced Impacts on Strength. Uniaxial testing was used to constrain the behaviour of samples under compressive loading (Figure 6(a)). The data show typical stressstrain relationships, such as documented in Heap et al. [61], transitioning from an initial concave-upward segment to 


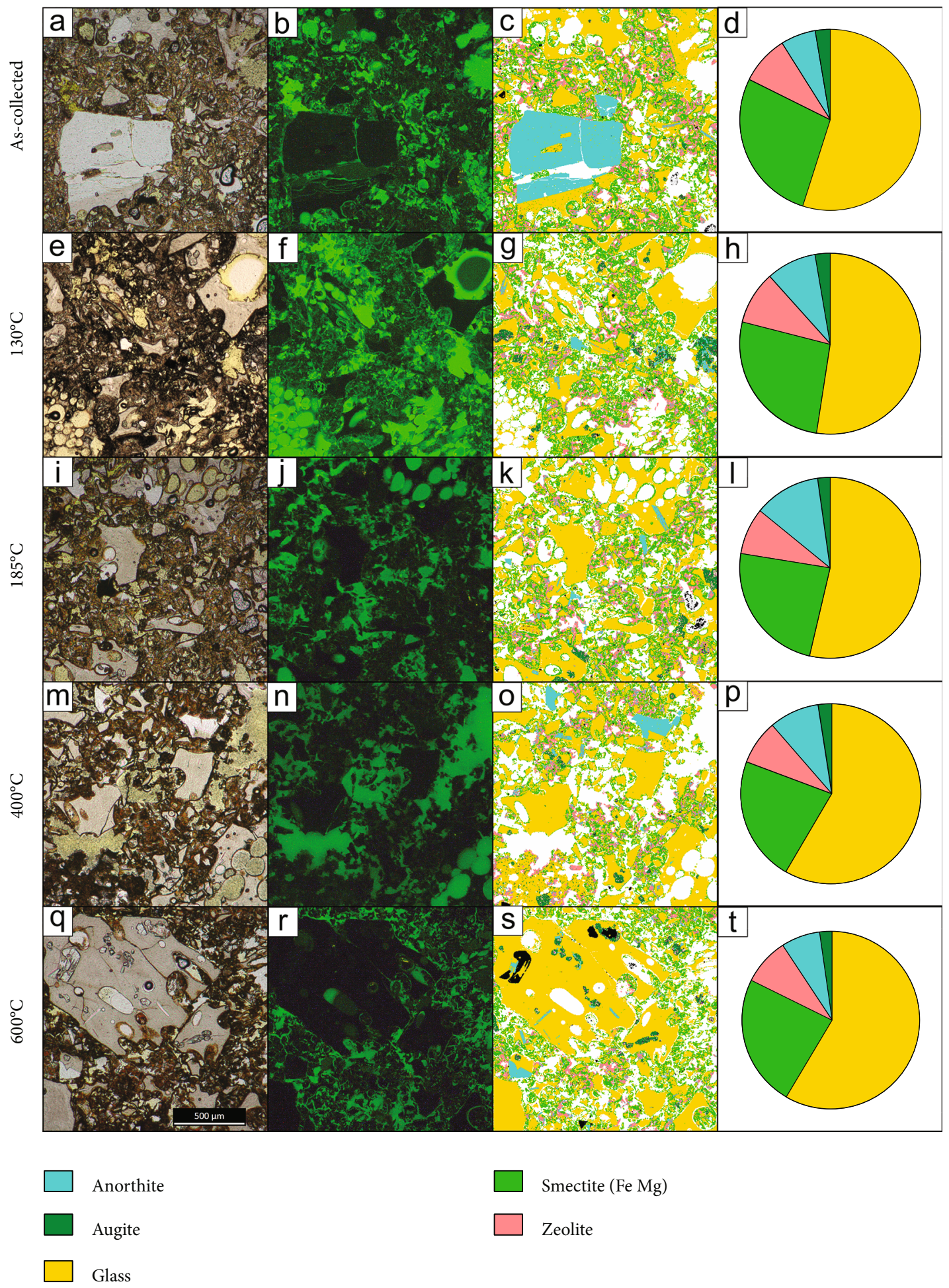

FIgURe 3: Petrographic analysis for the as-collected and TT samples. The as-collected images are presented in (a-d), $130^{\circ} \mathrm{C}$ TT images in $(\mathrm{e}-\mathrm{h}), 185^{\circ} \mathrm{C}$ TT images in (i-l), $400^{\circ} \mathrm{C}$ TT images in $(\mathrm{m}-\mathrm{p})$, and $600^{\circ} \mathrm{C}$ TT images in (q-t); each image shows $1.5 \mathrm{~mm}^{2}$. Plane polarised light images are displayed in column 1 (Supplementary Figure 2 shows an annotated example of the petrographic images); ultraviolet images in reflected light of samples impregnated by fluorescent epoxy highlight porosity in column 2; QEMSCAN mineralogy maps at $4 \mu \mathrm{m}$ resolution in column 3 highlight mineral distribution; and quantified mineralogy pie charts from $20 \mu \mathrm{m}$ resolution QEMSCAN maps in column 4 (images are shown in Supplementary Figures 3-6). 
TABLE 2: Mineralogy for the as-collected material and for each treatment temperature quantified from the QEMSCAN image analysis at $20 \mu \mathrm{m}$ resolution (see Supplementary Figures 2-7). Note that changes to mineral structure, such as dissolution, are not captured by QEMSCAN. Values are normalised by the background (pore space) of each image.

\begin{tabular}{lccccc}
\hline Temperature experienced: & $20^{\circ} \mathrm{C}$ & $130^{\circ} \mathrm{C}$ & $185^{\circ} \mathrm{C}$ & $400^{\circ} \mathrm{C}$ & $600^{\circ} \mathrm{C}$ \\
\hline Glass (\%) & 53.8 & 51.4 & 53.0 & 57.9 & 57.6 \\
Smectite (Fe Mg) (\%) & 26.8 & 26.3 & 23.6 & 22.0 & 23.4 \\
Zeolite (\%) & 8.8 & 9.2 & 8.2 & 8.0 & 8.3 \\
Anorthite (\%) & 6.0 & 8.8 & 11.8 & 8.7 & 6.9 \\
Augite (\%) & 2.6 & 2.6 & 2.1 & 2.5 & 2.3 \\
Quartz (\%) & 0.3 & 0.3 & 0.3 & 0.3 & 0.4 \\
Actinolite (\%) & 0.3 & 0.3 & 0.2 & 0.2 & 0.1 \\
Others (\%) & 1.2 & 1.0 & 0.7 & 0.2 & 0.6 \\
Unclassified (\%) & 0.2 & 0.1 & 0.2 & 0.2 & 0.4 \\
Total (\%) & 100 & 100 & 100 & 100 & 100 \\
\hline
\end{tabular}

being quasilinear, followed by a concave-downward segment. In terms of absolute strain, the beginning and end of the quasilinear segments are not correlated with treatment temperature; however, the average strain of the linear portion decreases from $0.0034-0.0037$ in the as-collected 130 and $185^{\circ} \mathrm{C}$ samples to $0.0021-0.0023$ in the 400 and $600^{\circ} \mathrm{C}$ samples. As the 400 and $600^{\circ} \mathrm{C}$ samples experience more strain prior to failure than the as-collected and lower temperature samples, the shortening of the linear portion also corresponds to a significantly smaller proportion of the total stress-strain curve. The average gradient of the linear segment, which is associated with rock elasticity and is used to calculate Young's modulus (Figure 7(d)), also decreases with temperature beyond $400^{\circ} \mathrm{C}$, from between $\sim 1.3 \mathrm{GPa}$ and 1.56 $\mathrm{GPa}$ for the as-collected 130 and $185^{\circ} \mathrm{C}$ samples, to between $\sim 0.7 \mathrm{GPa}$ and $1.07 \mathrm{GPa}$ for the 400 and $600^{\circ} \mathrm{C}$ samples. The data show that the as-collected, surficial hyaloclastites exhibit a range of compressive strength from 8 to $10 \mathrm{MPa}$ (Figure 6(a)). Upon thermal treatment to 130 and $185^{\circ} \mathrm{C}$, we observe no systematic changes in the sample strength, although the data show wider scatter (Figure 6(a)), whilst samples thermally treated to 400 and $600^{\circ} \mathrm{C}$ weaken to between 4.2 and 6.8 MPa (Figure 6(a)).

Triaxial testing was used to constrain the behaviour of the hyaloclastite at a confining pressure of $5 \mathrm{MPa}$ (Figure 6(b)), which is representative of $\sim 300 \mathrm{~m}$ depth in the geothermal reservoir, assuming nominal rock and water densities of $2500 \mathrm{~kg} \mathrm{~m}^{-3}$ and $800 \mathrm{~kg} \mathrm{~m}^{-3}$, respectively [62]. Under such a confinement, the compressive strength of the as-collected hyaloclastite is $\sim 30 \mathrm{MPa}$, exhibiting a small stress drop upon rupture. Following thermal treatment at 130 and $185^{\circ} \mathrm{C}$, hyaloclastite exhibits a moderate strength decrease of up to 3.3 and 7.2 $\mathrm{MPa}$, respectively; yet, the stress-strain curves show systematic reductions in the stress drop upon rupture. Hyaloclastites subjected to higher temperatures of 400 or $600^{\circ} \mathrm{C}$ reveal contrasting behaviour in which samples tend to yield at lower differential stress, beginning to flow upon strain (Figure 6(b)); the one exception to this is the strongest sample, treated at $400^{\circ} \mathrm{C}$, which was texturally comparable to the other TT samples and yet shows mechanical behaviour similar to samples subjected to lower temperatures. Thus, thermal debilitation slightly weakens hyaloclastite and promotes a shift towards a ductile regime (Figure 6(b); Supplementary Table 2).

Brazilian tests were used to quantify the UTS of hyaloclastite (Figure 6(c); Supplementary Table 3). The as-collected hyaloclastite shows a near-linear stress loading curve and a UTS of $1.5 \mathrm{MPa}$. Upon thermal treatment to 130,185 , and $400^{\circ} \mathrm{C}$, we note a systematic weakening trend down to $0.6 \mathrm{MPa}$. Hyaloclastites subjected to the higher $600^{\circ} \mathrm{C}$ temperature do not weaken further but rather undergo more compaction prior to failure.

The peak strengths from the UCS, TXL, and UTS curves show a decreasing trend with porosity and TT (Figure 7(a)). Analysis of the UCS (Figure 7(b)), UTS (Figure 7(c)), and Young's modulus data (Figure 7(d)) shows they follow trends published for igneous rocks. Young's moduli obtained from the uniaxial (Figure 6(a)) and triaxial (Figure 6(b)) strength tests reveal a negative correlation with the connected porosity of samples, imparted by thermal treatment. Young's moduli obtained during uniaxial tests are generally lower than the equivalent triaxial results for a given porosity (Figure $7(\mathrm{~d})$ ).

The data presented here highlights the substantial impact of thermal treatment on the mineralogical, physical, and mechanical properties of altered reservoir rocks as present in active geothermal systems. Notably, increasing temperature results in lower smectite contents, higher porosity and permeability, and lower compressive and tensile strengths.

\section{Interpretation and Discussion}

4.1. Application of Laboratory Results to the Field. The investigation on the thermal stability of hyaloclastite present up to $1300 \mathrm{~m}$ depth in the shallow geothermal reservoir within the Krafla caldera provides important constraints on the properties of a common reservoir rock. However, due to the physically and mineralogically heterogeneous nature of hyaloclastite, studies at a laboratory scale $[8,48]$ are challenging to apply to field scales. The variations noted in the mineralogical assemblage of the surficial hyaloclastite studied here (Tables 1 and 2) are likely due to the physically and mineralogically variable source volcaniclastic components, despite being prepared from a single $40 \mathrm{~cm}$ block. Influence of this heterogeneity continuously transpires in the physical and mechanical characterisation of both the as-collected and TT samples, particularly highlighted by the contrasting permeability behaviour in Figure 5(a). Heterogeneity at the field scale may be markedly greater due to sorting and componentry [35] and the degree of alteration, particularly between hyaloclastites exposed to different fluid chemistry [19]. Therefore, the data and trends of thermal treatment are most applicable to smectite-bearing hyaloclastite exposed to meteoric-sourced fluids, such as at Krafla. Here, we interpret the influence of thermal treatment on the physical and mechanical properties of surficial hyaloclastite and compare the resultant properties with those obtained from cores sampled from depth. 


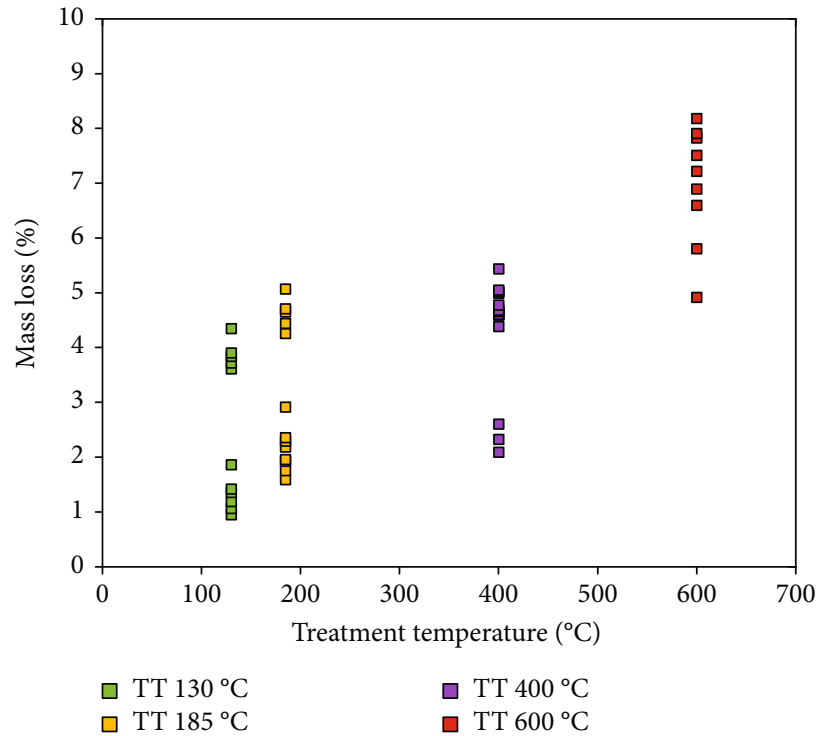

(a)

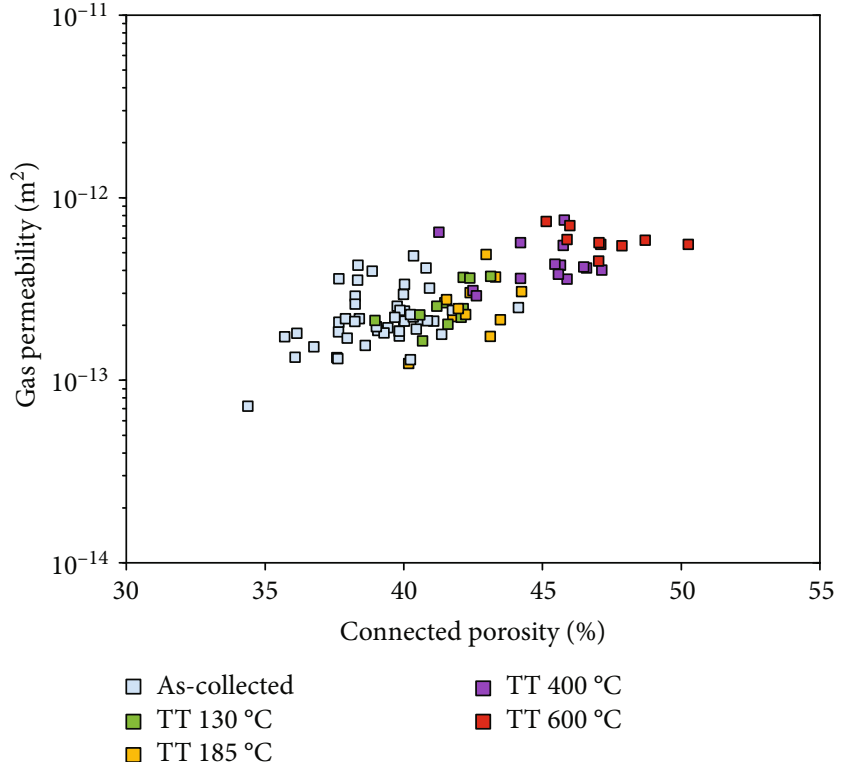

(b)

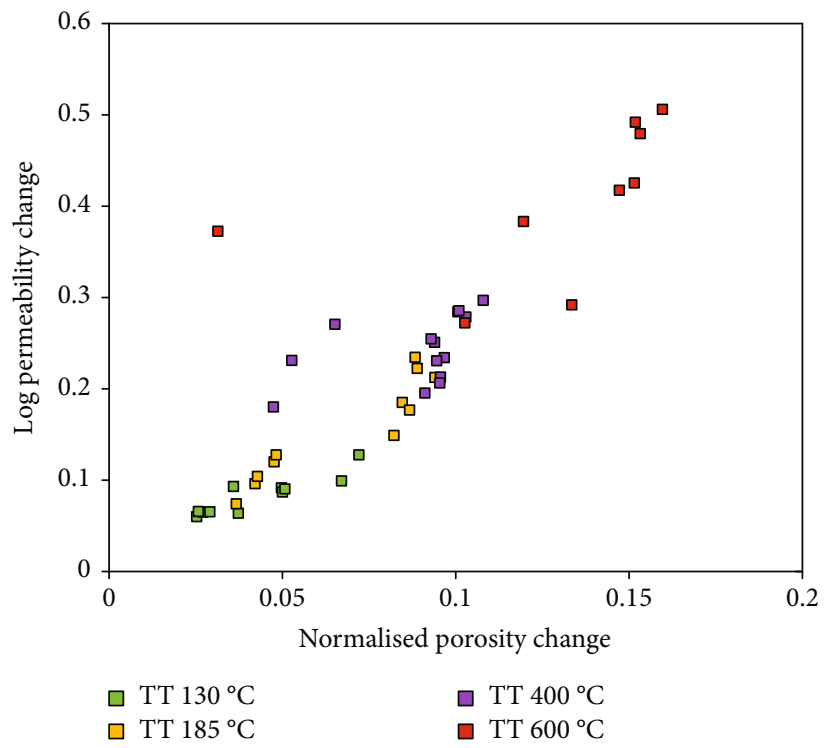

(c)

FIgURE 4: Influence of TT on mass, porosity, and permeability. (a) Percentage mass change induced by thermal treatment for each 26 mm by $52 \mathrm{~mm}$ core, showing increasing mass reduction up to temperatures of $600^{\circ} \mathrm{C}$. (b) Increasing porosity-gas permeability of the as-collected and post-treatment samples as the treatment temperature is increased. (c) Normalised porosity and gas permeability change from the as-collected materials, showing a linear permeability change with increased normalised porosity change.

4.2. Impact of Temperature on the Mineralogical Assemblage of Hyaloclastite. Thermally treating hyaloclastite results in mass loss (Figure 2(a)), which can be used as a proxy for water loss in hydrous clays $[53,64,65]$. However, it is important to note that phyllosilicates, such as smectite, comprise a group of highly variable minerals that have distinct dehydration and dehydroxylation temperatures [66]. The reduction in the $\mathrm{d}(001)$ spacing in the XRD data (Supplementary Figure 1) is linked to the dissociation of the palagonite matrix resulting from smectite dehydration (Table 1). In detail, gylcolation firstly causes the $\mathrm{d}(001)$ peak to increase to $16.2 \AA$, as ethylene glycol replaces water in the interlayer space [67]; subsequent heating to $400^{\circ} \mathrm{C}$ for 12 hours drives ethylene glycol and water out of the interlayer space, decreasing the $\mathrm{d}(001)$ peak to $10 \AA$ [68]. Therefore, the reduction in smectite quantity with temperature is more accurately a case of progressive alteration (dehydration), which ultimately damages the crystal structure and reduces the effectiveness of the diffraction process. This produces smaller peaks in the diffractogram, which are interpreted as a lower mineral quantity; a similar reduction in smectite is not observed in the QEMSCAN data (Table 2) as only chemistry is monitored, not crystal structure. The lowtemperature $\left(<200^{\circ} \mathrm{C}\right)$ devolatilisation reactions identified 


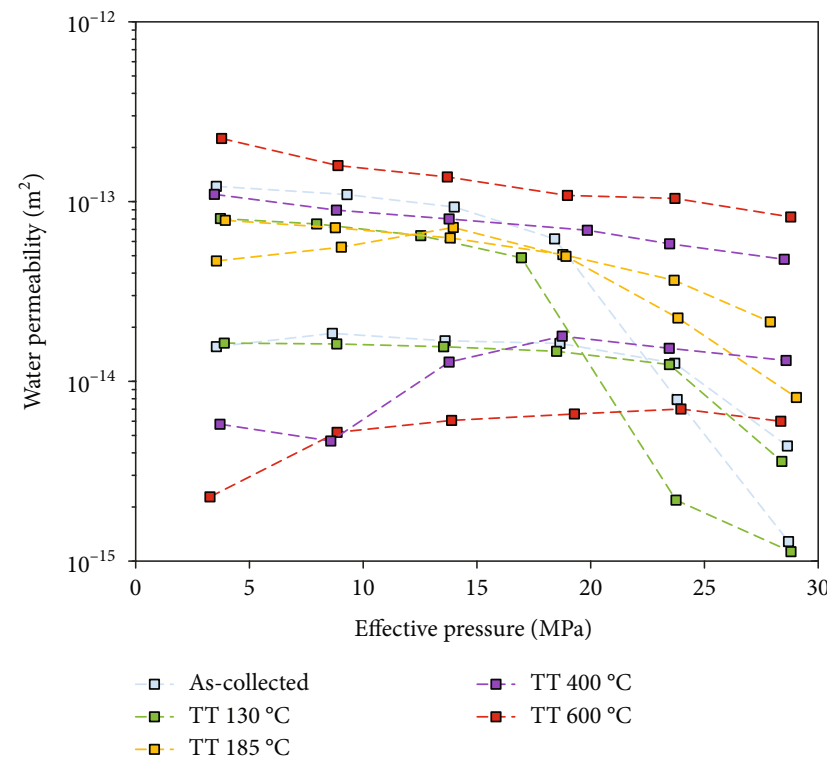

(a)

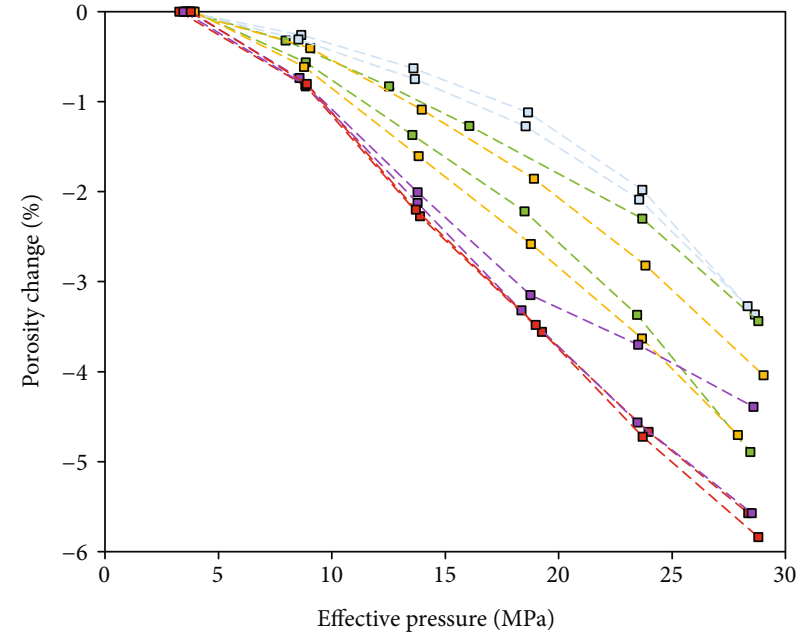

(b)

Figure 5: The effect of loading on permeability and porosity. (a) Water permeability evolution against effective pressure. Samples exhibit a large range of responses and degree of scatter for a given TT. (b) Pore space collapse associated with increased effective pressure. Change in porosity is measured from $\sim 3.5$ effective pressure.

in the TGA-DSC data (Figures 2(a) and 2(b)) correlate well with the clay-separated XRD results (Supplementary Figure 1). The endothermic DSC peaks at $130^{\circ} \mathrm{C}$ and $185^{\circ} \mathrm{C}$ (Figure 2(b)) are encompassed within the $100-200^{\circ} \mathrm{C}$ dehydration window expected for saponite [69] and are likely due to the loss of sorbed water and interlayer water [68]. Saponite commonly precipitates from hydrothermal fluids found at depth [70, 71] and has been previously identified in cores from the Krafla geothermal reservoir [19]. The subsurface samples have less prominent saponite dehydration peaks due to a combination of lower saponitechlorite ratios and the higher in situ temperatures potentially causing partial dehydration prior to measurement [60]. The ability of smectite to rehydrate is dependent upon temperature, cation size, and saturation state [72]. Under many conditions, saponite is able to fully or partially rehydrate [73], suggesting the impacts discussed here may be partially reversible.

The $525-560^{\circ} \mathrm{C}$ endothermic peaks identified in the $556 \mathrm{~m}$ and $732 \mathrm{~m}$ samples (Figure 2(b)) are indicative of chlorite dehydroxylation from interstratified saponite-chlorite [68], resulting in a second higher temperature mass loss response (Figure 2(a)). The endothermic peak and associated mass loss are greater within the $732 \mathrm{~m}$ sample, suggesting it has a lower saponite-chlorite ratio than the $556 \mathrm{~m}$ sample. The combined saponite-chlorite content at Krafla increases erratically from $19 \%$ at the surface to $~ 50 \%$ at depth, not including glass content [60], suggesting thermally induced devolatilisation reactions at depth may be more impactful. However, note that all of the TGA-DSC measurements were performed under near-atmospheric pressure conditions and that increased pressure from the subsurface may suppress dehydration and dehydroxylation to higher temperatures [74], such that the temperatures for reactions presented here are potentially conservative compared to those occurring in situ. Following the devolatilisation of the phyllosilicates, the bulk rock density increases due to the residual minerals emitting light elements; upon compaction, this may impact the physical and mechanical rock properties.

4.3. Impact of Temperature on the Thermal Expansivity of Hyaloclastite. In addition to mass loss, the thermal treatment of hyaloclastite also results in direct volume change as the palagonite phyllosilicate phases are prone to swelling at low temperatures and subsequently collapse following thermally induced dehydration and dehydroxylation (e.g., $>500^{\circ} \mathrm{C}$; Figure 2(d)). However, identifying the swelling properties of individual components in a porous polymineralic rock is challenging due to the potential for overlapping responses and the possibility of accommodating expansion into the pore space [75]. In the surface samples, the impact of saponite dehydration in the thermomechanical data (Figure $2(\mathrm{~d})$ ) is subtle, causing a minor compaction of the bulk rock, followed by significant compaction correlating with the chlorite dehydroxylation temperature. This suggests that hyaloclastite retains structural integrity throughout saponite dehydration whilst a higher temperature reaction correlated to chlorite dehydroxylation causes a partial loss of cohesion between the palagonite matrix and the supported clasts. The similar, more distinct collapse in the relatively chlorite-rich $732 \mathrm{~m}$ sample at $575^{\circ} \mathrm{C}$ correlates well with the endothermic peak at $560^{\circ} \mathrm{C}$ and the mass loss identified between $515^{\circ} \mathrm{C}$ and $615^{\circ} \mathrm{C}$ (Figures 2(a) and 2(b)). However, the $556 \mathrm{~m}$ subsurface sample has lower saponite-chlorite ratios and does not exhibit this collapse; instead, the response shows limited thermal expansion throughout the heating profile. Thus, we find that hyaloclastites with thermally stable mineralogical assemblage expand with 


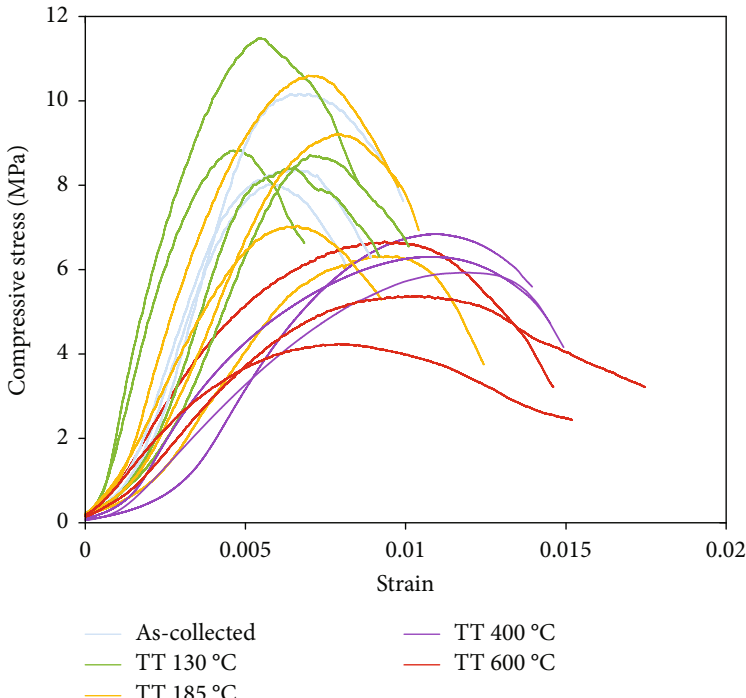

(a)

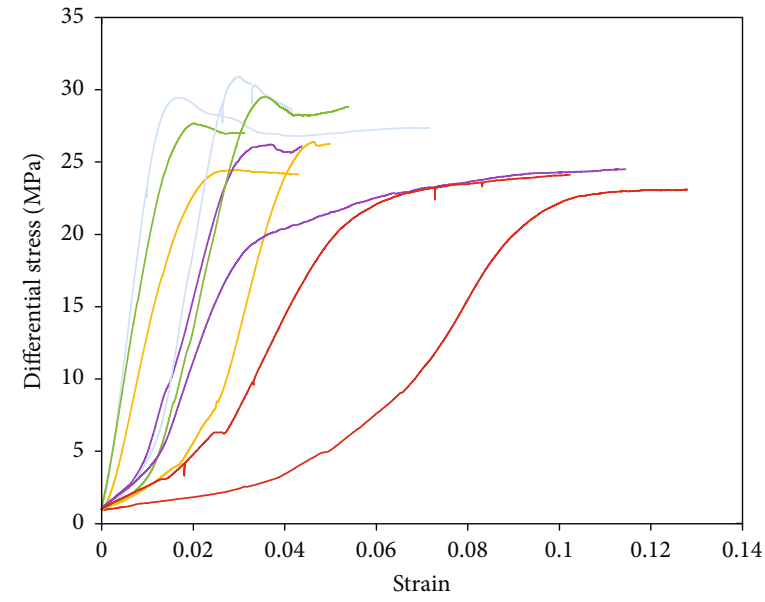

(b)

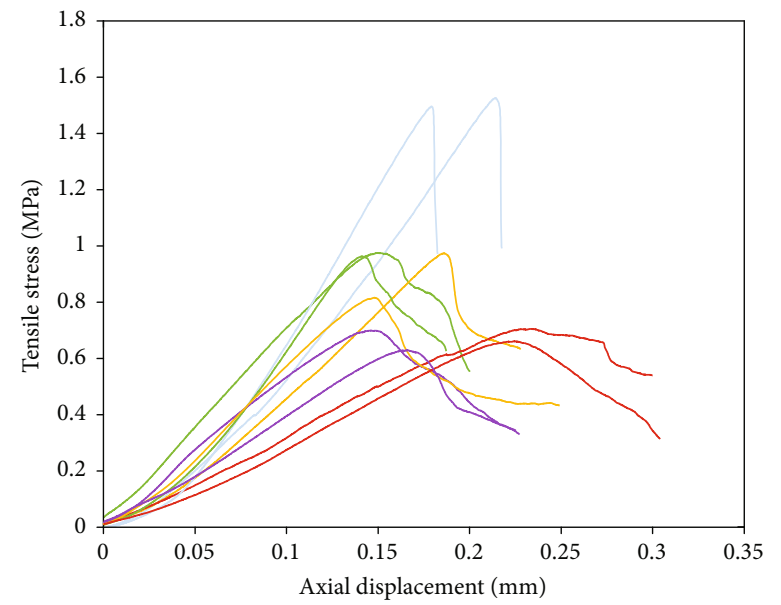

(c)

FIgURE 6: The impact of TT on strength. (a) UCS curves at $10^{-5} \mathrm{~s}^{-1}$ strain rate. (b) TXL curves at $10^{-5} \mathrm{~s}^{-1}$ strain rate. (c) UTS curves, using the Brazilian disc method, at $10^{-4} \mathrm{~s}^{-1}$ diametric equivalent strain rate. For increased TT, all strength test types display a weakening trend and an increased accommodation of strain prior to failure (additional tensile strength curves are shown in Supplementary Figure 8).

temperature, whereas unstable assemblages may breakdown and cause contraction, as exemplified by the thermal treatment of surficial hyaloclastites (Figure 2(d)). The thermal expansion responses measured under near-atmospheric pressure conditions, and any damage attributed to them, may be pushed to higher temperatures under the increased pressure conditions associated with burial, as dehydration is suppressed [74]. However, without a change in temperature, an increase in pressure alone does not result in smectite dehydration [76].

The occurrence of substantial acceleration in thermal expansion above $640^{\circ} \mathrm{C}$ from the $70 \mathrm{~m}$ samples (Figure 2(d)) coincided with vesiculation of glass clasts in the experimental products; this was not reproduced in samples from other depths, despite the abundance of glass in all samples (Figure 3). In detail, thermal expansivity started to accelerate around $600^{\circ} \mathrm{C}$, following a moderate endothermic peak
(Figure 2(b)), associated with crossing of the glass transition for hydrated basaltic glass [77, 78], expected in shallow, water-rich environments [43]. Beyond this temperature, structural relaxation of the stress enabled water exsolution and increased vesiculation that sustained the heat absorption leading to a prolonged endothermic plateau (Figure 2(d)), as the samples rapidly expanded (Figure 2(b)).

4.4. Impact of Temperature on the Porosity and Permeability of Hyaloclastite. The mass loss associated with the dehydration/dehydroxylation of the phyllosilicate phases during thermal treatment of hyaloclastite is also responsible for the increase in porosity and permeability displayed in Figure 4. A temperature increase can strongly impact the physical attributes for fluid storage capacity and flow, as the basal spacing of palagonite decreases upon devolatilisation, causing densification and generating intrinsically connected 

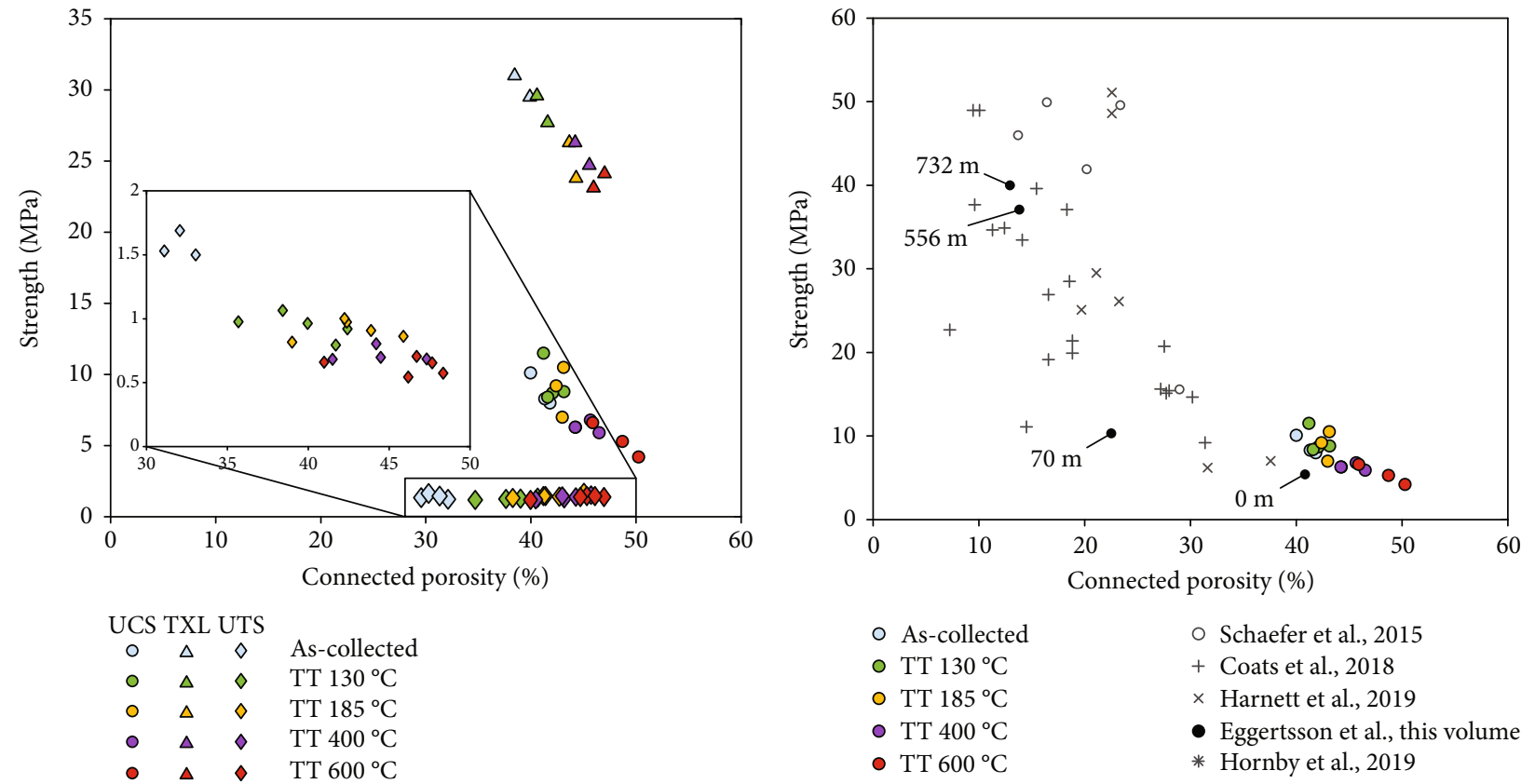

(a)

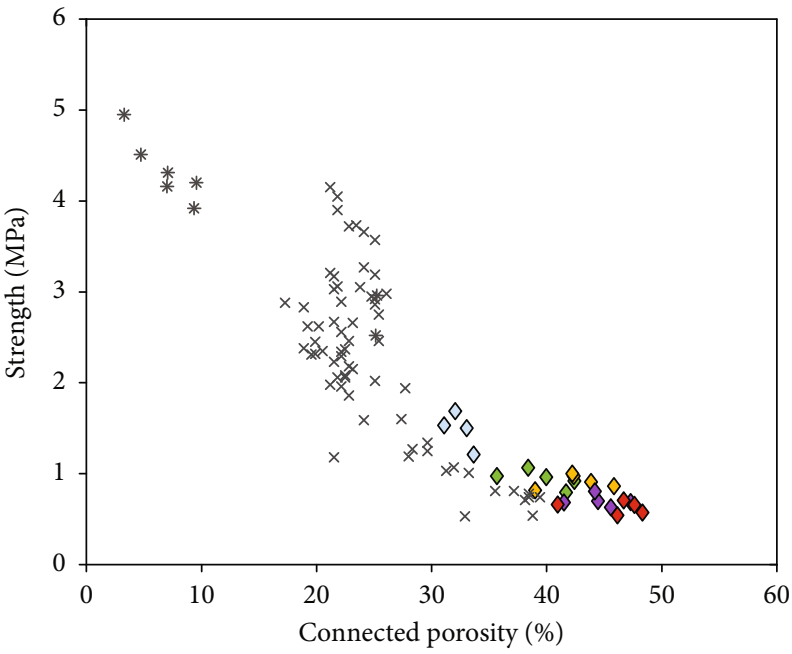

(c)

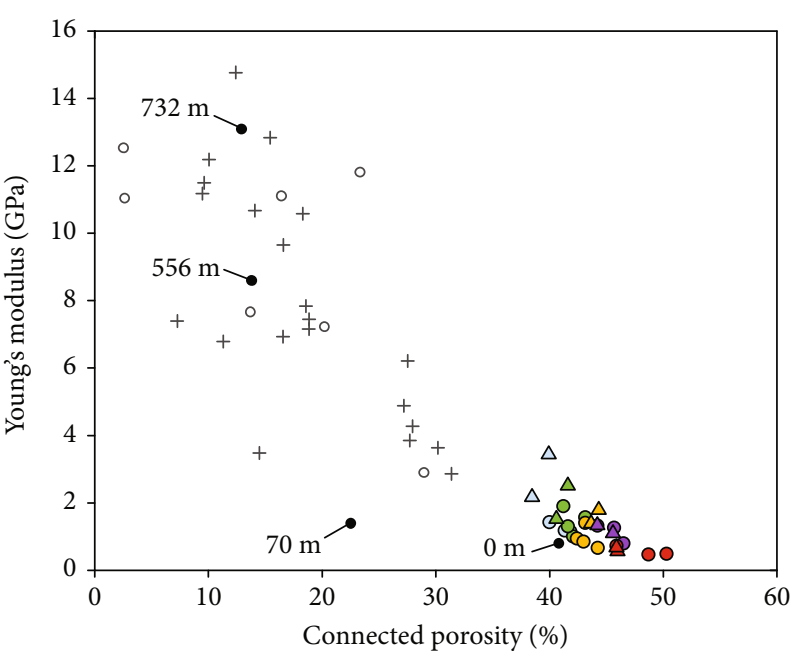

(d)

Figure 7: Porosity control on UCS, TXL, UTS, and Young's modulus. (a) Comparison of UCS, TXL, and UTS peak strength of hyaloclastite for each treatment temperature. All strength test types show weakening associated with increased TT and porosity. (b) UCS results follow the general trend for igneous rocks, with TT decreasing strength proportional to the porosity increase. However, TT increases porosity, whilst hyaloclastite densifies and strengthens with depth (values show depth of sampling; [63]). (c) UTS results, regardless of TT, also fall within the general trend for igneous rocks. (d) Young's modulus from the UCS and TXL tests follow the general trend for igneous rocks (values show depth of sampling; [63]).

micropores [79]. In detail, the amount and ratio of saponitechlorite available for reaction provides a first-order control on the maximum extent of porosity possibly created by excursion to high temperature. As such, the timedependent crystallisation of sideromelane to palagonite [47] suggests that older hyaloclastite units, which can contain more phyllosilicates, are more susceptible to temperature increases and the resultant enhancements to the porous permeable network. Thus, the lithology-specific initial glass chemistry, hydrothermal fluid chemistry, and pressure- temperature conditions will therefore impact the potential for the temperature-induced mineralogical and physical alterations that regulate the evolution of the storage capacity and permeability of a reservoir subjected to thermal fluctuations. In addition, the reservoir fluid properties will impact the hydration state of the phyllosilicate minerals; the increased scatter from water permeability (Figure 5(a)) to gas permeability (Figure 4(b)) is likely a result of interaction between the pore fluid and the minerals (especially clays) lining the permeable network. 
At the sample scale, the lack of additional fractures in the TT samples suggests that dehydration/dehydroxylation is the primary mechanism responsible for porosity and permeability gain. Whilst cracking due to thermal stresses during heating and cooling has been shown to impart changes in the physical properties of some rocks, we advance that thermally generated cracks may not necessarily accumulate in hyaloclastite. Thermal cracking has been ascribed to the generation of stresses resulting from (1) a mismatch in thermal expansion or contraction between minerals, (2) thermal expansion anisotropy within a mineral, and (3) thermal gradients across a sample $[80,81]$. Hyaloclastites are fragmental rocks with variable degrees of cohesion arising from the presence of palagonite, so thermal stressing is expected to cause minimal damage in hyaloclastite as mineral expansion is in part buffered by palagonite, which is weaker than typical volcanic minerals, and due to the abundant and ubiquitous pore space that accommodates expansion without stress development. Eggertsson et al. [8] showed that thermal stimulation may avoid fracture genesis and result in negligible permeability change, independent of the cooling rate, if the thermal stress associated with expansion is alleviated by preferential closure of the existing porous network, such as present in these samples (Figure 2(b)). We also note no evidence of intra-mineral thermal cracking induced by anisotropic expansion. However, it is possible that inter-phenocryst/glass fragment microfracturing occurred, as noted in hyaloclastite quenched from $350^{\circ} \mathrm{C}$ [82], but that textural evidence was subsequently overprinted by phyllosilicate dissolution. Thermal microfractures are often non-pervasive in nature $[6,49]$, suggesting the limited contribution they provide to permeability is unable to account for the permeability evolution revealed in this study. Deformation-induced macrofractures may induce a more substantial permeability increase $[83,84]$, yet such damage is not imparted by thermal treatment alone. However, the impact of thermal fracturing on the broad range of volcanic lithologies is yet to be well constrained, as discussed in Heap et al. [61], and very few studies focus on highly altered material and the impact of pressure on thermal stimulation [52].

A further measure of changing material properties as a response to TT can be the sensitivity of materials to effective pressure; water permeability shows a negative correlation with effective pressure as porosity is isolated (Figure 5). The as-collected samples as well as those TT to $130^{\circ} \mathrm{C}$, and to $185^{\circ} \mathrm{C}$, show a significant drop in porosity and permeability during confinement to effective pressures above $17.5 \mathrm{MPa}$ that is not observed in the 400 and $600^{\circ} \mathrm{C}$ TT samples. The samples that have been TT to higher temperatures exhibit contrasting evolution of permeability and porosity with effective pressure, where porosity decreases linearly and more significantly than the lower TT samples, but permeability is not as sensitive to increasing effective pressure, suggesting that the porous network remains highly connected even as effective pressure is increased. There is one exception (thermally treated to $400^{\circ} \mathrm{C}$ ) which shows an increase in permeability with increasing effective pressure, and a less significant reduction in porosity; this could be a result of irreversible compaction in the sample whereby connected pore space was generated, yet we observed no textural evidence for this.

4.5. Impact of Temperature on the Mechanical Properties of Hyaloclastite. The addition of thermal stress can also impact the resultant mechanical properties of hyaloclastite. In particular, a pressure increase causes a relatively abrupt reduction in pore space and permeability within the ascollected hyaloclastite and the samples thermally treated to $130^{\circ} \mathrm{C}$ (Figure 5). This transition from elastic to inelastic compaction upon loading is termed $P^{*}$ [85]. Beyond $P^{*}$, compaction and grain crushing lead to a loss of pore space available for fluid flow $[8,50,86]$. Figure $5(\mathrm{~b})$ indicates that $P^{*}$ shifts to lower effective pressure with thermal treatment. The samples thermally treated up to $185^{\circ} \mathrm{C}$ exhibit poorly defined changes in permeability associated with $P^{*}$, and samples treated to higher temperatures develop no distinct changes with $P^{*}$. This suggests that thermal treatment promotes a style of compaction that has limited impact on permeability, despite higher rates of porosity loss (Figure 5(b)).

The devolatilisation of the palagonite matrix results in a weakening of the rock, both in tension and in compression, where the UCS is 6-10 times greater than the UTS (Figure 7(a)). The UTS of hyaloclastite decreased with TT and, following treatment at $600^{\circ} \mathrm{C}$, lost coherence and underwent more deformation before rupture (Figure 6(c)). The mode of deformation evolves similarly in compression, as noted by the onset of dilation occurring at lower stress and the accommodation of more substantial strain hardening prior to failure (Figure 6(a)), concordant with the lower Young's modulus upon increasing treatment temperature (Figure 7(d)). Deformation under an effective pressure of $5 \mathrm{MPa}$ accentuated the distinction between the low TT $\left(\leq 185^{\circ} \mathrm{C}\right)$ and high $\mathrm{TT}\left(\geq 400^{\circ} \mathrm{C}\right)$ hyaloclastites as they macroscopically behaved in a brittle and ductile manner, respectively (Figure 6(b)).

The resultant strengths measured in all test types display a porosity control, irrespective of the stress field experienced (Figure $7(\mathrm{a})$ ), which follows the common porosity-strength trend (Figures $7(\mathrm{~b})$ and $7(\mathrm{c})$ ) for a range of igneous rock types, regardless of TT $[7,11,63,87,88]$. The treatment temperature has a strong impact on porosity (Figure 4(c)), thereby further influencing mechanical compaction; however, comparison with strength and Young's modulus data collected from subsurface samples [63] shows that temperature alone cannot explain the mechanical changes occurring within the reservoir, instilling the roles of compaction and alteration on strength changes. In part, this is due to the opposing influences of temperature and compaction on porosity; however, in concert, increased temperature will create additional pore space that may enable more complete compaction and densification to occur at depth [63]. The change in style, from a dominantly brittle to ductile failure, may be explained by a change in geometry of the pore space (e.g., Figures 3(b) and 3(r)), as dehydration increases the connectivity and irregularity of the desiccated pore network [89]. The influence of porosity in controlling sample strength can be further assessed using micromechanical modelling such as 


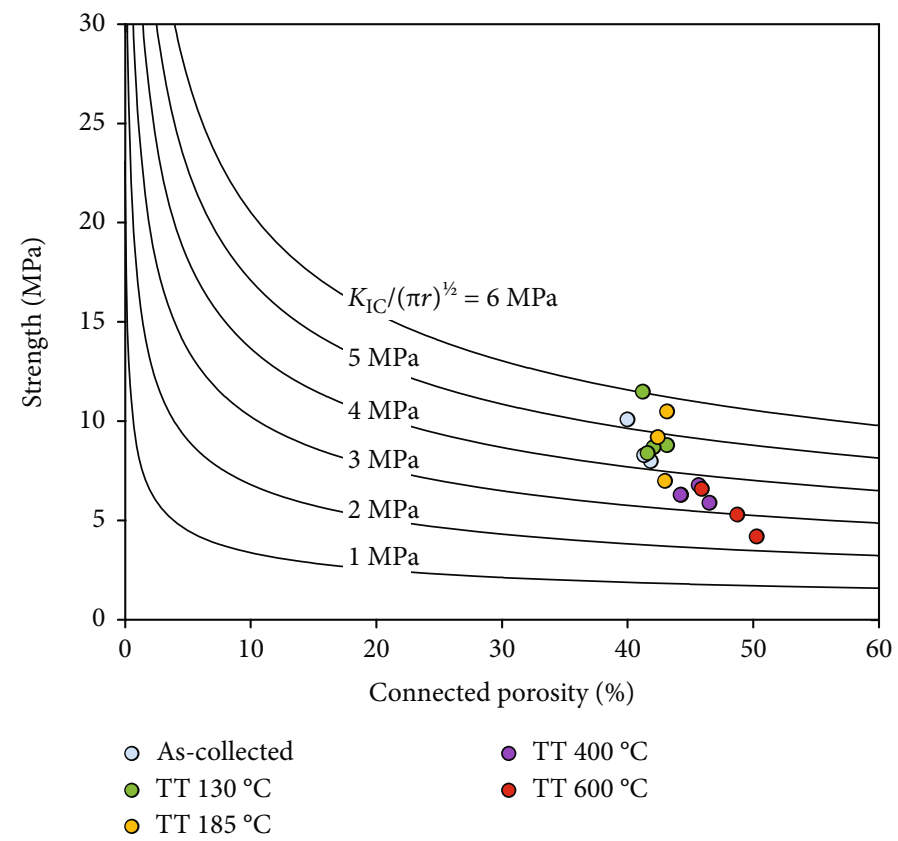

FIGURE 8: UCS measurements compared against the pore-emanated crack model suggest an increase in porosity and pore-widening results in weakening.

the pore-emanated crack model developed by Sammis and Ashby [90] and analytically modified by Zhu et al. [91] to derive the UCS, $\sigma_{\mathrm{UCS}}$ :

$$
\sigma_{\mathrm{UCS}}=\frac{1.325}{\phi^{0.414}} \frac{K_{\mathrm{IC}}}{\sqrt{\pi r}} .
$$

The strength is dependent upon the fracture toughness (or critical stress intensity factor), $K_{\mathrm{IC}}$, the porosity $(\phi)$, and pore size $(r)$. This model was demonstrated to successfully approximate the UCS of limestone [91] and porous glass sintered in the laboratory [92] but show arguable efficiency to approximate the strength of heterogeneous, coherent volcanic rocks, owing to their common abundance of microfractures [7, 61]. Here, the UCS values decrease as porosity increases with TT (Figure 8), suggesting that $K_{\mathrm{IC}} / \sqrt{\pi r}$ would decrease from $\sim 5 \mathrm{MPa}$ down to $\sim 3 \mathrm{MPa}$. Assuming $K_{\mathrm{IC}}$ remains constant within a single lithology (even upon smectite hydration), the analysis would suggest that the reduction in strength and $K_{\mathrm{IC}} / \sqrt{\pi r}$ may be the result of pore creation and widening, as suggested by Heap et al. [61] when evaluating the mechanisms underlying thermally induced rock weakening. However, the applicability of the poreemanated crack model to hyaloclastite is questionable as the pore space is highly irregular and rock failure is promoted by increasingly more pervasive fracture architecture in thermally treated hyaloclastites.

4.6. Implications for Hyaloclastite-Bearing Geothermal Reservoirs. The temperatures investigated here cover the range of conditions hyaloclastite generally encounters in the shallow geothermal reservoir at Krafla [93] and encompass several important mineral transitions within the palagonite matrix. The transition from smectite to chlorite is common in hyaloclastite-bearing geothermal regions and is predominately controlled by temperature, assuming similar fluid chemistry [19]. Saponite is dominant below $200^{\circ} \mathrm{C}$, transitions to saponite-chlorite interlayers between 200 and $240^{\circ} \mathrm{C}$, and is fully replaced with chlorite beyond $240^{\circ} \mathrm{C}$ [19]. Therefore, these results provide a first-order approximation of the changes occurring in hyaloclastite during burial and regional heating. Well and core logging at Krafla suggests that the deepest hyaloclastite units at $1300 \mathrm{~m}$ naturally experience temperatures of approximately $320^{\circ} \mathrm{C}$ [94] and thus would have been subjected to the full range of transitions. However, as the temperature profile is spatially variable across the field, the depth of mineral transitions range over several hundred meters [94].

Some geothermal regions, such as Krafla, are also host to magmatic intrusions that can transfer heat to their host rock, inducing much greater localised temperature changes [5]. Similarly, harnessing of very hot fluids, as experienced during flow testing of a $2100 \mathrm{~m}$ deep, near-magma borehole during IDDP-1 [21], resulted in fluids up to $550^{\circ} \mathrm{C}$ reaching the wellhead. Thus, a shallow magmatic intrusion or superheated/supercritical fluid ingress during flow testing can alter the mineralogical, physical, and mechanical properties of shallow hyaloclastite, common in conventional geothermal reservoirs. This may promote more efficient fluid flow in geothermal fields; yet, fluid flow in clay-bearing rocks is partially controlled by the chemistry of the fluids which can interact with the host [95]; thus, the impact of fluid chemistry on fluid flow is expected to decrease upon palagonite dissociation. Here, comparing the surficial hyaloclastite with the hyaloclastites sampled from the reservoir, we find that the thermally induced mass loss and mineralogical distribution of the deep hyaloclastites cannot be explained by simple heating events, as those performed in our experiments, but rather 
evoke the importance of pressure-temperature history and chemistry in the hydrothermal system. For instance, the onset of saponite dehydration may increase by several hundred degrees by increasing pressure to $30 \mathrm{MPa}$ [74], such as through rock burial or glaciation, suggesting the physical and mechanical changes detailed here may be shifted to higher temperatures for buried samples. Additionally, the impact of pore fluid pressure may suppress dehydration reactions to higher temperatures than recorded in the dry measurements presented here [96]. As such, the interplay between temperature and pressure produces a complex relationship with the resultant mineralogical, physical, and mechanical properties. Geothermal regimes with low effective pressure and high temperature, such as the shallow subsurface, may exhibit a positive correlation between the temperature experienced and the resultant porosity and permeability, whilst in a deeper high-pressure environment, the breakdown from thermal fluctuations, if any, may promote compaction.

Anthropogenic-induced compaction may possibly occur due to the extraction of geothermal fluids inducing a reduction in the reservoir pore pressure [97]; this would increase the effective pressure and subsequently raise the depth threshold of compaction [98], locally altering the dominant permeability regime. Porosity change associated with temperature fluctuations may also influence the depth threshold of compaction. Similarly, a temperature reduction caused by fluid extraction may result in rehydration and swelling due to the potentially reversible nature of smectite dehydration, thereby clogging fluid pathways.

4.7. Implications for Magma Intrusions in Hyaloclastite. The intrusion of magma into hyaloclastite may result in complex intrusion-host rock interaction, evolution, and feedback, owing to variable degrees of devolatilisation and compaction. Initially, an intrusion would bake the margin, promoting phyllosilicate devolatilisation that improves the porous permeable network, allowing for efficient fluid flow; however, this may be accompanied by changes in strength and a transition from brittle to ductile deformation, which may instead favour compaction of the hyaloclastite along the magma boundary, causing a decrease in permeability [99] and compartmentalisation of fluid flow [100]. The construction versus destruction of a permeable porous network may have crucial impacts for the evolution of shallow magmatic systems. Firstly, the liberation of fluids from smectite and chlorite may, if trapped, locally increase pore pressure and generate induced seismicity akin to hydraulic fracturing [101] and, in extreme cases, cause phreatic explosions, as seen at Viti crater, Krafla [102]. Secondly, the volatiles liberated may promote magma hydration and increase the likelihood of explosive activity [103] or result in cooling and quenching of the magma. Thirdly, and similarly, margin compaction and shutting of the permeable network may limit magma outgassing, which again increases the likelihood of explosive volcanism. And finally, magma intrusion may result in viscous relaxation of sideromelane or melting of hyaloclastite, thus generating new magma, which may mix and interact with the intrusion. Thus, the evolution and feedback between magma and hyaloclastite are likely to be very complex depend- ing on the nature (e.g., chemistry, temperature) and size of an intrusion and on the state and properties of hyaloclastites. We suggest that further research should be undertaken to better understand these complex feedback systems and the implications for the volcanic and geothermal processes.

\section{Conclusion}

In this study, we show that rock heterogeneity impacts the mineralogical, physical, and mechanical properties of hyaloclastite, which are susceptible to thermal fluctuations experienced within geothermal fields. This is due to the devolatisation of the palagonite matrix, composed of varying phyllosilicate minerals which are sourced from the tendency of metastable basaltic glass to crystallise and produce a smectite-dominant (i.e., saponite) palagonite matrix in cool settings $\left(<200^{\circ} \mathrm{C}\right)$ and a chlorite-dominant matrix in hotter settings.

Thermal treatment of surficial hyaloclastite indicates that smectite dehydrates upon heating, with increased treatment temperature causing up to $10 \mathrm{wt} . \%$ mass loss at $700^{\circ} \mathrm{C}$. This dehydration, quantified at $130,185,400$, and $600^{\circ} \mathrm{C}$, results in an enhanced porous permeable network, a decreased compressive and tensile strength, a decreased Young's modulus, and a shift from brittle to ductile mode of deformation upon thermal treatment $\left(\geq 400^{\circ} \mathrm{C}\right)$, even at a moderate effective pressure of $5 \mathrm{MPa}$ (as experienced at shallow depths in a geothermal system). We assess the impact of temperature on hyaloclastite sampled from boreholes at 70,556, and $732 \mathrm{~m}$ depth in the reservoir, finding that the glass in the shallow rock may have been hydrated whereas the deeper rocks contain abundant chlorite, which dehydroxylates at $\sim 560^{\circ} \mathrm{C}$.

The increased temperatures and pressures experienced in geothermal fields will reduce the hydration state of phyllosilicate minerals, causing weakening and potentially lowering the depth threshold for compaction. Such deformation in geothermal systems and areas surrounding magmatic bodies may result in the construction/destruction of fluid pathways and the compartmentalisation of reservoirs, possibly impacting the progression of volcanic activity.

\section{Data Availability}

The data used to support the findings of this study are included within the article and supplementary information.

\section{Conflicts of Interest}

The authors declare that they have no conflicts of interest

\section{Acknowledgments}

This study has been conducted as part of a $\mathrm{PhD}$ supported by the Natural Environment Research Council (NERC) EAO Doctoral Training Partnership that is funded by NERC (NE/L002469/1), whose support is gratefully acknowledged. This research was further supported by Landsvirkjun National Power Company of Iceland and by Landsvirkjun's Energy Research fund, in addition to a Starting Grant from 
the European Research Council (ERC) on Strain Localisation in Magma (SLiM, no. 306488) and a Research Fellowship of the Leverhulme Trust (RF 2019-526\4) to Y. Lavallée and an Early Career Fellowship of the Leverhulme Trust (ECR 2016-325) granted to J.E. Kendrick.

\section{Supplementary Materials}

Supplementary Tables 1-3: physical and mechanical data for the surficial samples, including density, porosity, permeability, strength, and Young's modulus change associated with thermal treatment. Supplementary Figure 1: X-ray diffractograms of the as-collected, glycolated, and unglycolated surficial samples. Supplementary Figures 2-6: QEMSCAN mineral distribution images, at $20 \mu \mathrm{m}$ resolution, for the as-collected and thermally treated surficial samples. Supplementary Figure 7: annotated examples of the petrographic images presented in figure 3 of the main text. Figure S8: additional tensile strength curves for the as-collected and TT surficial materials. (Supplementary Materials)

\section{References}

[1] H. Ármannsson, T. Fridriksson, J. Benjamínsson, and T. Hauksson, "History of gas in Geothermal Fluids, Krafla, Northeast Iceland," Earth \& Planetary Science, vol. 7, pp. 23-26, 2013.

[2] S. De Simone, V. Vilarrasa, J. Carrera, A. Alcolea, and P. Meier, "Thermal coupling may control mechanical stability of geothermal reservoirs during cold water injection," Physics and Chemistry of the Earth, Parts $A / B / C$, vol. 64, pp. 117-126, 2013.

[3] H. Tulinius, H. Correia, and O. Sigurdsson, Stimulating a high enthalpy well by thermal cracking, World Geothermal Congress, 2000.

[4] G. Axelsson, S. S. Gylfadóttir, and T. Egilson, "Temperature condition modelling for well IDDP-1 in Krafla," in Proceedings of SIMS 2012, the 53rdScandinavian Simulation and Modelling Society Conference, Reykjavik, Iceland, 2012.

[5] J. Schauroth, F. B. Wadsworth, B. Kennedy et al., "Conduit margin heating and deformation during the $\mathrm{AD} 1886$ basaltic Plinian eruption at Tarawera volcano, New Zealand," Bulletin of Volcanology, vol. 78, no. 2, p. 12, 2016.

[6] J. Browning, P. Meredith, and A. Gudmundsson, "Coolingdominated cracking in thermally stressed volcanic rocks," Geophysical Research Letters, vol. 43, no. 16, pp. 8417-8425, 2016.

[7] R. Coats, J. E. Kendrick, P. A. Wallace et al., "Failure criteria for porous dome rocks and lavas: a study of Mt. Unzen, Japan," Solid Earth, vol. 9, no. 6, pp. 1299-1328, 2018.

[8] G. H. Eggertsson, Y. Lavallée, J. E. Kendrick, and S. H. Markússon, "Improving fluid flow in geothermal reservoirs by thermal and mechanical stimulation: the case of Krafla volcano, Iceland," Journal of Volcanology and Geothermal Research, vol. 391, article 106351, 2020.

[9] M. J. Heap, S. Mollo, S. Vinciguerra et al., "Thermal weakening of the carbonate basement under Mt. Etna volcano (Italy): implications for volcano instability," Journal of Volcanology and Geothermal Research, vol. 250, pp. 42-60, 2013.

[10] J. E. Kendrick, R. Smith, P. Sammonds, P. G. Meredith, M. Dainty, and J. S. Pallister, "The influence of thermal and cyclic stressing on the strength of rocks from Mount St.
Helens, Washington," Bulletin of Volcanology, vol. 75, no. 7, p. 728, 2013.

[11] L. N. Schaefer, J. E. Kendrick, T. Oommen, Y. Lavallée, and G. Chigna, "Geomechanical rock properties of a basaltic volcano," Frontiers in Earth Science, vol. 3, 2015.

[12] P. A. Siratovich, M. J. Heap, M. C. Villenueve, J. W. Cole, and T. Reuschlé, "Physical property relationships of the Rotokawa Andesite, a significant geothermal reservoir rock in the Taupo Volcanic Zone, New Zealand," Geothermal Energy, vol. 2, no. 1, p. 10, 2014.

[13] A. Ghassemi and G. S. Kumar, "Changes in fracture aperture and fluid pressure due to thermal stress and silica dissolution/precipitation induced by heat extraction from subsurface rocks," Geothermics, vol. 36, no. 2, pp. 115-140, 2007.

[14] D. K. Bird, P. Schiffman, W. A. Elders, A. E. Williams, and S. D. McDowell, "Calc-silicate mineralization in active geothermal systems," Economic Geology, vol. 79, no. 4, pp. 671695, 1984.

[15] M. J. Heap, Y. Lavallée, A. Laumann et al., "The influence of thermal-stressing (up to $1000 \mathrm{C}$ ) on the physical, mechanical, and chemical properties of siliceous-aggregate, high-strength concrete," Construction and Building Materials, vol. 42, pp. 248-265, 2013.

[16] G. S. Kumar and A. Ghassemi, "Numerical modeling of nonisothermal quartz dissolution/precipitation in a coupled fracture-matrix system," Geothermics, vol. 34, no. 4, pp. 411-439, 2005.

[17] P. A. Siratovich, M. C. Villeneuve, J. W. Cole, B. M. Kennedy, and F. Bégué, "Saturated heating and quenching of three crustal rocks and implications for thermal stimulation of permeability in geothermal reservoirs," International Journal of Rock Mechanics and Mining Sciences, vol. 80, pp. 265-280, 2015.

[18] J. Clearwater, L. Azwar, M. Barnes, I. Wallis, and R. Holt, "Changes in injection well capacity during testing and plant start-up at Ngatamariki," Changes, vol. 19, p. 25, 2015.

[19] H. Kristmannsdóttir, "Alteration of basaltic rocks by hydrothermal-activity at $100-300^{\circ} \mathrm{C}$," in Developments in Sedimentology, pp. 359-367, Elsevier, 1979.

[20] N. Marks, P. Schiffman, R. A. Zierenberg, H. Franzson, and G. Ó. Fridleifsson, "Hydrothermal alteration in the Reykjanes geothermal system: insights from Iceland deep drilling program well RN-17," Journal of Volcanology and Geothermal Research, vol. 189, no. 1-2, pp. 172-190, 2010.

[21] A. K. Mortensen, P. Egilson, B. Gautason, S. Árnadóttir, and Á. Guðmundsson, "Stratigraphy, alteration mineralogy, permeability and temperature conditions of well IDDP-1, Krafla, NE-Iceland," Geothermics, vol. 49, pp. 31-41, 2014.

[22] K.-Y. Kim, Y.-S. Park, G.-P. Kim, and K.-H. Park, "Dynamic freshwater-saline water interaction in the coastal zone of Jeju Island, South Korea," Hydrogeology Journal, vol. 17, no. 3, pp. 617-629, 2009.

[23] J. M. Matter, W. S. Broecker, S. R. Gislason et al., "The CarbFix Pilot Project-Storing carbon dioxide in basalt," Energy Procedia, vol. 4, pp. 5579-5585, 2011.

[24] O. K. Zakharova and V. V. Spichak, "Geothermal fields of Hengill Volcano, Iceland," Journal of Volcanology and Seismology, vol. 6, no. 1, pp. 1-14, 2012.

[25] D. L. Nielson and S. G. Stiger, "Drilling and evaluation of Ascension\# 1, a geothermal exploration well on Ascension Island, South Atlantic Ocean," Geothermics, vol. 25, no. 4-5, pp. 543-560, 1996. 
[26] K. H. Wohletz, "Explosive magma-water interactions: thermodynamics, explosion mechanisms, and field studies," Bulletin of Volcanology, vol. 48, no. 5, pp. 245-264, 1986.

[27] J. Honnorez and P. Kirst, "Submarine basaltic volcanism: morphometric parameters for discriminating hyaloclastites from hyalotuffs," Bulletin of Volcanology, vol. 39, no. 3, pp. 441-465, 1975.

[28] R. Hekinian, F. Pineau, S. Shilobreeva, D. Bideau, E. Gracia, and M. Javoy, "Deep sea explosive activity on the MidAtlantic Ridge near $3450^{\prime} \mathrm{N}$ : magma composition, vesicularity and volatile content," Journal of Volcanology and Geothermal Research, vol. 98, no. 1-4, pp. 49-77, 2000.

[29] A. S. Davis and D. A. Clague, "Hyaloclastite from Miocene seamounts offshore Central California: compositions, eruption styles, and depositional processes," Explosive Subaqueous Volcanism, vol. 140, pp. 129-142, 2003.

[30] N. C. Mitchell, "Susceptibility of mid-ocean ridge volcanic islands and seamounts to large-scale landsliding," Journal of Geophysical Research - Solid Earth, vol. 108, no. B8, 2003.

[31] M. Ferrer, J. Seisdedos, and L. I. de Vallejo, The role of hyaloclastite rocks in the stability of the volcanic island flank of Tenerife, Taylor Francis Group, London, 2010.

[32] P. Schiffman, R. J. Watters, N. Thompson, and A. W. Walton, "Hyaloclastites and the slope stability of Hawaiian volcanoes: insights from the Hawaiian Scientific Drilling Project's 3-km drill core," Journal of Volcanology and Geothermal Research, vol. 151, no. 1-3, pp. 217-228, 2006.

[33] S. P. Jakobsson and M. T. Gudmundsson, "Subglacial and intraglacial volcanic formations in Iceland," Jökull, vol. 58, pp. 179-196, 2008.

[34] A. Jarosch, M. T. Gudmundsson, T. Högnadóttir, and G. Axelsson, "Progressive cooling of the hyaloclastite ridge at Gjálp, Iceland, 1996-2005," Journal of Volcanology and Geothermal Research, vol. 170, no. 3-4, pp. 218-229, 2008.

[35] H. H. Schopka, M. T. Gudmundsson, and H. Tuffen, “The formation of Helgafell, southwest Iceland, a monogenetic subglacial hyaloclastite ridge: sedimentology, hydrology and volcano-ice interaction," Journal of Volcanology and Geothermal Research, vol. 152, no. 3-4, pp. 359-377, 2006.

[36] S. G. Bergh and G. E. Sigvaldason, "Pleistocene mass-flow deposits of basaltic hyaloclastite on a shallow submarine shelf, South Iceland," Bulletin of Volcanology, vol. 53, no. 8, pp. 597-611, 1991.

[37] P. Kokelaar, "Magma-water interactions in subaqueous and emergent basaltic," Bulletin of Volcanology, vol. 48, no. 5, pp. 275-289, 1986.

[38] K. H. Wohletz and M. F. Sheridan, "Hydrovolcanic explosions; II, evolution of basaltic tuff rings and tuff cones," American Journal of Science, vol. 283, no. 5, pp. 385-413, 1983.

[39] J. V. Wright and R. A. F. Cas, Volcanic successions, modern and ancient: a geological approach to processes, products, and successions, Allen \& Unwin/Chapman \& Hall, London; Boston, 1988.

[40] J. Van Otterloo, R. A. F. Cas, and C. R. Scutter, "The fracture behaviour of volcanic glass and relevance to quench fragmentation during formation of hyaloclastite and phreatomagmatism," Earth-Science Reviews, vol. 151, pp. 79-116, 2015.

[41] J. S. Denton, H. Tuffen, J. S. Gilbert, and N. Odling, "The hydration and alteration of perlite and rhyolite," Journal of the Geological Society of London, vol. 166, no. 5, pp. 895904, 2011.
[42] E. H. Oelkers and S. R. Gislason, "The mechanism, rates and consequences of basaltic glass dissolution: I. An experimental study of the dissolution rates of basaltic glass as a function of aqueous $\mathrm{Al}, \mathrm{Si}$ and oxalic acid concentration at $25^{\circ} \mathrm{C}$ and $\mathrm{pH}$ $=3$ and 11," Geochimica et Cosmochimica Acta, vol. 65, no. 21, pp. 3671-3681, 2001.

[43] T. E. Cerling, F. H. Brown, and J. R. Bowman, "Low-temperature alteration of volcanic glass: hydration, $\mathrm{Na}, \mathrm{K}, 18 \mathrm{O}$ and Ar mobility," Chemical Geology: Isotope Geoscience Section, vol. 52, no. 3-4, pp. 281-293, 1985.

[44] F. W. von Aulock, A. R. L. Nichols, B. M. Kennedy, and C. Oze, "Timescales of texture development in a cooling lava dome," Geochimica et Cosmochimica Acta, vol. 114, pp. 7280, 2013.

[45] G. Berger, J. Schott, and M. Loubet, "Fundamental processes controlling the first stage of alteration of a basalt glass by seawater: an experimental study between $200^{\circ}$ and $320^{\circ} \mathrm{C}$," Earth and Planetary Science Letters, vol. 84, no. 4, pp. 431-445, 1987.

[46] N. A. Stroncik and H.-U. Schmincke, "Evolution of palagonite: Crystallization, chemical changes, and element budget," Geochemistry, Geophysics, Geosystems, vol. 2, no. 7, 2001.

[47] A. Drief and P. Schiffman, "Very low-temperature alteration of sideromelane in hyaloclastites and hyalotuffs from Kilauea and Mauna Kea volcanoes: implications for the mechanism of palagonite formation," Clays and Clay Minerals, vol. 52, no. 5, pp. 622-634, 2004.

[48] H. Franzson, G. H. Gudhfinnsson, H. M. Helgadóttir, and J. Frolova, Porosity, density and chemical composition relationships in altered Icelandic hyaloclastites, CRC Press Inc., 2010.

[49] M. J. Heap, Y. Lavallée, A. Laumann, K.-U. Hess, P. G. Meredith, and D. B. Dingwell, "How tough is tuff in the event of fire?," Geology, vol. 40, no. 4, pp. 311-314, 2012.

[50] J. D. Bedford, D. R. Faulkner, H. Leclère, and J. Wheeler, "High-resolution mapping of yield curve shape and evolution for porous rock: the effect of inelastic compaction on porous bassanite," Solid Earth, vol. 123, no. 2, pp. 1217-1234, 2018.

[51] Y. Bernabé, U. Mok, and B. Evans, "Permeability-porosity relationships in rocks subjected to various evolution processes," Pure and Applied Geophysics, vol. 160, no. 5, pp. 937-960, 2003.

[52] S. P. Mordensky, B. M. Kennedy, M. C. Villeneuve et al., "Increasing the permeability of hydrothermally altered andesite by transitory heating," Geochemistry, Geophysics, Geosystems, vol. 20, no. 11, pp. 5251-5269, 2019.

[53] R. E. Milliken and J. F. Mustard, "Quantifying absolute water content of minerals using near-infrared reflectance spectroscopy," Journal of Geophysical Research, vol. 110, no. E12, 2005.

[54] B. T. Gudmundsson and S. Arnórsson, "Geochemical monitoring of the Krafla and Námafjall geothermal areas, N-Iceland," Geothermics, vol. 31, no. 2, pp. 195-243, 2002.

[55] H. Ármannsson, A. Gudmundsson, and B. S. Steingrímsson, "Exploration and development of the Krafla geothermal area," Jökull, vol. 37, pp. 13-30, 1987.

[56] H. Tuffen and J. M. Castro, "The emplacement of an obsidian dyke through thin ice: Hrafntinnuhryggur, Krafla Iceland," Journal of Volcanology and Geothermal Research, vol. 185, no. 4, pp. 352-366, 2009. 
[57] E. Gautason, A. Blischke, and P. E. Danielsen, Krafla: Borun tveggjakjarnaholna, KH-5 og KH-6 veturinn 2006-2007, ÍSOR technical report 07075, Reykjavik, 2007.

[58] L. J. Klinkenberg, "The permeability of porous media to liquids and gases," Drilling and Production Practice, American Petroleum Institute, 1941.

[59] P. Forchheimer, "Wasserbewegung durch boden. Z," Zeitschrift des Vereines Deutscher Ingenieure, vol. 45, pp. 1782$1788,1901$.

[60] L. Lévy, B. Gibert, F. Sigmundsson et al., "The role of smectites in the electrical conductivity of active hydrothermal systems: electrical properties of core samples from Krafla volcano, Iceland," Geophysical Journal International, vol. 215, no. 3, pp. 1558-1582, 2018.

[61] M. J. Heap, Y. Lavallée, L. Petrakova et al., "Microstructural controls on the physical and mechanical properties of edifice-forming andesites at Volcán de Colima, Mexico," Solid Earth, vol. 119, no. 4, pp. 2925-2963, 2014.

[62] S. W. Scott, C. Covell, E. Júlíusson et al., "A probabilistic geologic model of the Krafla geothermal system constrained by gravimetric data," Geothermal Energy, vol. 7, no. 1, 2019.

[63] G. H. Eggertsson, J. E. Kendrick, J. Weaver et al., "Compaction of hyaloclastite from the active geothermal system at Krafla volcano, Iceland," Geofluids, In press.

[64] J. L. Bishop, C. M. Pieters, and J. O. Edwards, "Infrared spectroscopic analyses on the nature of water in montmorillonite," Clays and Clay Minerals, vol. 42, no. 6, pp. 702-716, 1994.

[65] A. S. Yen, B. C. Murray, and G. R. Rossman, "Water content of the Martian soil: laboratory simulations of reflectance spectra," Journal of Geophysical Research, Planets, vol. 103, no. E5, pp. 11125-11133, 1998.

[66] S. Yariv, D. Ovadyahu, A. Nasser, U. Shuali, and N. Lahav, "Thermal analysis study of heat of dehydration of tributylammonium smectites," Thermochimica Acta, vol. 207, pp. 103$113,1992$.

[67] R. Mosser-Ruck, K. Devineau, D. Charpentier, and M. Cathelineau, "Effects of ethylene glycol saturation protocols on XRD patterns: a critical review and discussion," Clays and Clay Minerals, vol. 53, no. 6, pp. 631-638, 2005.

[68] H. Shirozu, T. Sakasegawa, N. Katsumoto, and M. Ozaki, "Mg-chlorite and interstratified mg-chlorite/saponite associated with Kuroko deposits," Clay Science, vol. 4, pp. 305-321, 1975.

[69] Z. Malek, V. Balek, D. Garfinkel-Shweky, and S. Yariv, "The study of the dehydration and dehydroxylation of smectites by emanation thermal analysis," Journal of Thermal Analysis, vol. 48, no. 1, pp. 83-92, 1997.

[70] H. A. Alfredsson, E. H. Oelkers, B. S. Hardarsson, H. Franzson, E. Gunnlaugsson, and S. R. Gislason, "The geology and water chemistry of the Hellisheidi, SW-Iceland carbon storage site," International Journal of Greenhouse Gas Control, vol. 12, pp. 399-418, 2013.

[71] A. P. Gysi and A. Stefánsson, "Mineralogical aspects of $\mathrm{CO}_{2}$ sequestration during hydrothermal basalt alteration - $\mathrm{An}$ experimental study at 75 to $250{ }^{\circ} \mathrm{C}$ and elevated $\mathrm{pCO}_{2}$," Chemical Geology, vol. 306-307, pp. 146-159, 2012.

[72] M. Kawano and K. Tomita, "Dehydration and rehydration of saponite and vermiculite," Clays and Clay Minerals, vol. 39, no. 2, pp. 174-183, 1991.

[73] J. D. Russell and V. C. Farmer, "Infra-red spectroscopic study of the dehydration of montmorillonite and saponite," Clay Minerals Bulletin, vol. 5, no. 32, pp. 443-464, 1964.
[74] O. Vidal and B. Dubacq, "Thermodynamic modelling of clay dehydration, stability and compositional evolution with temperature, pressure and $\mathrm{H} 2 \mathrm{O}$ activity," Geochimica et Cosmochimica Acta, vol. 73, no. 21, pp. 6544-6564, 2009.

[75] H. W. Cooper and G. Simmons, "The effect of cracks on the thermal expansion of rocks," Earth and Planetary Science Letters, vol. 36, no. 3, pp. 404-412, 1977.

[76] L. C. Carniel, R. V. Conceição, N. Dani, V. F. Stefani, N. M. Balzaretti, and R. . Reis, "Structural changes of potassiumsaturated smectite at high pressures and high temperatures: application for subduction zones," Applied Clay Science, vol. 102, pp. 164-171, 2014.

[77] D. Giordano, J. K. Russell, and D. B. Dingwell, "Viscosity of magmatic liquids: a model," Earth and Planetary Science Letters, vol. 271, no. 1-4, pp. 123-134, 2008.

[78] G. Robert, A. G. Whittington, A. Stechern, and H. Behrens, "Heat capacity of hydrous basaltic glasses and liquids," Journal of Non-Crystalline Solids, vol. 390, pp. 19-30, 2014.

[79] I. Kolař́iková, R. Přikryl, R. Hanus, and E. Jelínek, “Thermal loading of smectite-rich rocks: natural processes vs. laboratory experiments," Clay Science, vol. 29, no. 3-4, pp. 215223, 2005.

[80] D. Richter and G. Simmons, "Thermal expansion behavior of igneous rocks," International Journal of Rock Mechanics and Mining Sciences \& Geomechanics Abstracts, vol. 11, no. 10, pp. 403-411, 1974.

[81] C. Yong and C. Wang, "Thermally induced acoustic emission in Westerly granite," Geophysical Research Letters, vol. 7, no. 12, pp. 1089-1092, 1980.

[82] P. A. Siratovich, I. Sass, S. Homuth, and A. Bjornsson, "Thermal stimulation of geothermal reservoirs and laboratory investigation of thermally-induced fractures," in Proceedings of Geothermal Resources Council Annual Meetingpp. 15291535, San Diego, California, USA, 2011.

[83] M. J. Heap and B. M. Kennedy, "Exploring the scaledependent permeability of fractured andesite," Earth and Planetary Science Letters, vol. 447, pp. 139-150, 2016.

[84] A. Lamur, J. E. Kendrick, G. H. Eggertsson, R. J. Wall, J. D. Ashworth, and Y. Lavallée, "The permeability of fractured rocks in pressurised volcanic and geothermal systems," Scientific Reports, vol. 7, no. 1, article 6173, 2017.

[85] J. Zhang, T.-F. Wong, and D. M. Davis, "Micromechanics of pressure-induced grain crushing in porous rocks," Journal of Geophysical Research, vol. 95, no. B1, pp. 341-352, 1990.

[86] M. J. Heap, J. I. Farquharson, P. Baud, Y. Lavallée, and T. Reuschlé, "Fracture and compaction of andesite in a volcanic edifice," Bulletin of Volcanology, vol. 77, no. 6, p. 55, 2015.

[87] C. E. Harnett, J. E. Kendrick, A. Lamur et al., "Evolution of mechanical properties of lava dome rocks across the 19952010 eruption of Soufrière Hills volcano, Montserrat," Frontiers in Earth Science, vol. 7, 2019.

[88] A. Hornby, Y. Lavallée, J. E. Kendrick et al., "Brittle-ductile deformation and tensile rupture of dome lava during inflation at Santiaguito, Guatemala," Journal of Geophysical Research: Solid Earth, vol. 124, no. 10, pp. 10107-10131, 2019.

[89] A. Bubeck, R. J. Walker, D. Healy, M. Dobbs, and D. A. Holwell, "Pore geometry as a control on rock strength," Earth and Planetary Science Letters, vol. 457, pp. 38-48, 2017.

[90] C. G. Sammis and M. F. Ashby, "The failure of brittle porous solids under compressive stress states," Acta Metallurgica, vol. 34, no. 3, pp. 511-526, 1986. 
[91] W. Zhu, P. Baud, and T. Wong, "Micromechanics of cataclastic pore collapse in limestone," Journal of Geophysical Research - Solid Earth, vol. 115, no. B4, 2010.

[92] J. Vasseur, F. B. Wadsworth, Y. Lavallée, K.-U. Hess, and D. B. Dingwell, "Volcanic sintering: timescales of viscous densification and strength recovery," Geophysical Research Letters, vol. 40, no. 21, pp. 5658-5664, 2013.

[93] G. S. Bodvarsson, S. M. Benson, O. Sigurdsson, V. Stefansson, and E. T. Eliasson, "The Krafla geothermal field, Iceland: 1. Analysis of well test data," Water Resources Research, vol. 20, no. 11, pp. 1515-1530, 1984.

[94] G. Fridleifsson, H. Ármannsson, and A. K. Mortensen, Geothermal conditions in the Krafla caldera with focus on well KG-26, Icel, Geosurvey Reykjavik, Icel, 2006.

[95] O. Kwon, B. E. Herbert, and A. K. Kronenberg, "Permeability of illite-bearing shale: 2 . Influence of fluid chemistry on flow and functionally connected pores," Journal of Geophysical Research: Solid Earth, vol. 109, no. B10, 2004.

[96] A. V. de Siqueira, C. Lobban, N. T. Skipper et al., "The structure of pore fluids in swelling clays at elevated pressures and temperatures," Journal of Physics: Condensed Matter, vol. 11, no. 47, pp. 9179-9188, 1999.

[97] P. Segall and S. D. Fitzgerald, "A note on induced stress changes in hydrocarbon and geothermal reservoirs," Tectonophysics, vol. 289, no. 1-3, pp. 117-128, 1998.

[98] J. Farquharson, M. J. Heap, P. Baud, T. Reuschlé, and N. R. Varley, "Pore pressure embrittlement in a volcanic edifice," Bulletin of Volcanology, vol. 78, no. 1, p. 6, 2016.

[99] J. I. Farquharson, F. B. Wadsworth, M. J. Heap, and P. Baud, "Time-dependent permeability evolution in compacting volcanic fracture systems and implications for gas overpressure," Journal of Volcanology and Geothermal Research, vol. 339, pp. 81-97, 2017.

[100] K. Senger, J. Tveranger, S. Planke et al., "Fluid flow around igneous intrusions: from outcrop to simulator," in LASI 5 Conference, pp. 2-3, Port Elizabeth, South Africa, 2012.

[101] W.-H. Wang and T. Wong, "Effects of reaction kinetics and fluid drainage on the development of pore pressure excess in a dehydrating system," Tectonophysics, vol. 370, no. 1-4, pp. 227-239, 2003.

[102] K. Mayer, B. Scheu, H. A. Gilg et al., "Experimental constraints on phreatic eruption processes at Whakaari (White Island volcano)," Journal of Volcanology and Geothermal Research, vol. 302, pp. 150-162, 2015.

[103] Y. Zhang, "A criterion for the fragmentation of bubbly magma based on brittle failure theory," Nature, vol. 402, no. 6762, pp. 648-650, 1999. 